
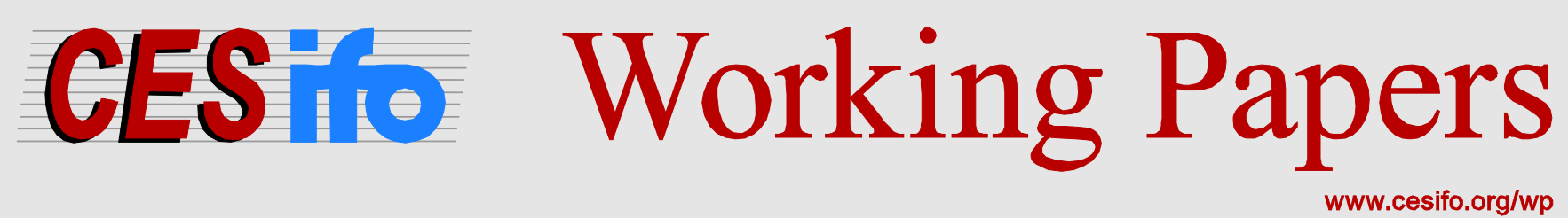

\title{
Policies against Human Trafficking: The Role of Religion and Political Institutions
}

\author{
Niklas Potrafke
}

CESIFO WORKING PAPER NO. 4278

CATEgory 2: Public CHOICE

JUNE 2013

An electronic version of the paper may be downloaded

- from the SSRN website:

- from the RePEc website:

- from the CESifo website:

WWW.SSRN.com

www.RePEc.org

www.CESifo-group.org/wp

\section{CESifo}




\title{
Policies against Human Trafficking: The Role of Religion and Political Institutions
}

\begin{abstract}
I investigate empirically the role of religion and political institutions in policies against human trafficking, using the new 3P Anti-trafficking Policy Index. The dataset contains 175 countries. The results show that governments in countries with Christian majorities implement stricter anti-trafficking policies than countries with Muslim majorities. The differences between countries with Christian and Muslim majorities is pronounced in dictatorships but less so in democracies. The influence of religion on the overall 3P Anti-trafficking Policy Index is driven by protection and prevention policies. As compared to prosecution policies that mainly target the perpetrators of human trafficking, protection and prevention policies mainly protect the victims of human trafficking, i.e. predominantly women. The conclusions are consistent with other empirical findings regarding the association between religion, political institutions, and human development.
\end{abstract}

JEL-Code: F220, O150, O110, Z120, F590.

Keywords: human trafficking, religion, political institutions, human rights, gender equality.

\author{
Niklas Potrafke \\ Ifo Institute - Leibniz-Institute \\ for Economic Research \\ at the University of Munich \\ Poschingerstraße 5 \\ Germany - 81679 Munich \\ potrafke@ifo.de
}

24 May 2013 


\section{Introduction}

The human trafficking problem has worsened in many countries. The United Nations Office on Drugs and Crime (UNDOC) states that "a conservative estimate of the crime puts the number of victims at any one time at 2.5 million... it affects every region of the world and generates tens of billions of dollars in profits for criminals each year."2

Because human trafficking threatens national security and compromises domestic human rights (Cho and Vadlamannati 2012), anti-trafficking policies are an important instrument in human development policies. To combat human trafficking, the United Nations General Assembly (UNGA) adopted in the year 2000 the Convention against Transnational Organized Crime and its Protocol to Prevent, Suppress and Punish Trafficking in Persons, especially Women and Children. Cho et al. (2013a) have introduced the novel 3P Anti-Trafficking Policy Index, which measures to what degree government policies reflect these guidelines. Data is provided for up to 185 countries over the period 2000-2010. Cho et al. (2013a) and Cho and Vadlamannati (2012) exploit variance across countries and over time by using panel data to examine whether variables such as income per capita, corruption, rule of law, women's rights, voting behavior in the UNGA and spatial dependencies influence anti-trafficking policies. ${ }^{3}$ The results show, for example, that democracies and countries that combat corruption have implemented strict anti-trafficking policies.

A pertinent question is who the victims and culprits of human trafficking are. The UNDOC states that "victims of trafficking can be any age, and any gender. However, a disproportionate number of women are involved in human trafficking both as victims and as culprits. ${ }^{\prime 4}$ Because many of the victims are women and combatting human trafficking reinforces human rights, cultural traits and religion are likely to influence policies against human trafficking. Religion has been shown to influence human development and economic policy-making. Religion influences, for

\footnotetext{
2(http://www.unodc.org/unodc/en/humantrafficking/faqs.html\#Who_are_the_victims_and_culprits_of_human_trafficki ng - accessed on July 22, 2012).

${ }^{3}$ Akee et al. (2010) examine how ethnic fragmentation and conflict influence human trafficking. Using micro-data from Eastern Europe, Omar Mahmoud and Trebesch (2010) show that individual trafficking risks are much higher in regions with large emigration flows.

${ }^{4}$ (http://www.unodc.org/unodc/en/humantrafficking/faqs - accessed on July 22, 2012).
} 
example, gender equality: in the education system and the labor market, discrimination against women is quite prevalent in countries with Muslim majorities. By contrast, discrimination against women is less pronounced in countries with Christian majorities. I review the empirical evidence on gender discrimination in the next section. Religion has also been shown to influence political institutions which, in turn, influence human development and economic policies. Empirical studies examining how religion shapes human development and economic policy-making therefore need to consider feedback effects via political institutions.

I investigate empirically the role of religion and political institutions on policies against human trafficking as measured by the new 3P Anti-trafficking Policy Index and its sub indices on prosecution, protection and prevention policies. As compared to Cho et al. (2013a) and Cho and Vadlamannati (2012), I elaborate on how religion influences the 3P indices. I do not estimate panel data models but cross-sectional models, because the religion variables do not vary over time. A shortcoming of using cross-sectional data is, of course, to not exploit variation over time. I follow the related empirical literature by considering Islam, Christianity, Buddhism, Hinduism, and indigenous religions as the five major religion groups. My main focus is however on the difference between the two largest groups, Islam and Christianity. I elaborate on the types of religion on policies against human trafficking and not religion as such (vis-à-vis atheism). For encompassing surveys on the consequences of religion and religiosity see, for example, Iannaccone (1998).

\section{Background}

\subsection{Religious doctrines}

Religious doctrines do not appear to give rise to large differences in policies against human trafficking. Both Christian beliefs and Islamic law denounce human trafficking. Christian beliefs actually condemn human trafficking since it violates sexual morality and human dignity. Christians have been active in combating human trafficking (Zimmerman 2011). Christian convictions shaped, for example, the moral sensibilities of the abolitionist movements in the 18th and 19th 
century. After the British Member of Parliament William Wilberforce converted to Christianity, he campaigned against slave trade. Consequently, the Slave Trade Act was passed in 1807 and the Slavery Abolition Act was passed in 1837. To be sure, Christians also held slaves and some Christians even justified the practice of slavery on supposed grounds of Christian theology (Zimmerman 2011: 570). The social purity movements in the late 19th- and early 20th century and the religious freedom movements in the late 20th century constituted however a basis for the antitrafficking movements in the 21 st century. Discussing the relationship between Christianity and anti-trafficking in the United States, Bernstein (2010: 66) arrives at the result: "two different shifts in feminist and conservative Christian sexual politics have made the contemporary campaign against sex trafficking possible: the feminist shift from a focus on bad men inside the home to bad men outside the home, and the shift of a new generation of evangelical Christians from a focus on sexually improper women (as prior concerns with abortion suggest) to a focus on sexually dangerous men."

The position of the UNODC (2010) report Combatting trafficking in persons in accordance with the principles of Islamic law is that "Islamic law, though it does not specifically prohibit trafficking in persons, explicitly prohibits many of the acts and elements that constitute trafficking in persons. Islam is particularly explicit on the prohibition of slavery. Similarly, Islam prohibits sexual exploitation for profit" (UNODC 2010: 2). ${ }^{5}$

Islamic doctrine of consent needs to be distinguished from harmful customary practices such as female genital mutilation, forced feeding of women, son preference, early marriage etc. "Indeed, women and children are the targets of the most serious violations of human rights that occur in Muslim countries as a result of these harmful customary practices" (UNODC 2010: 28 f.). On human trafficking, especially women and children, in countries of the Middle East see Mattar (2002). The small differences in religious doctrines between Christian tenets and Islamic law

\footnotetext{
${ }^{5}$ Rubin (2011) elaborates on interest restrictions in Islam and Christianity and argues that underdevelopment in countries with Muslim majorities does not relate to Islam itself.
} 
deviate a great deal from empirical evidence on how, for example, gender equality is obeyed in countries with Christian and Muslim majorities.

\subsection{Religion and human development}

Religion has been shown to affect gender equality. Countries with Catholic majorities were among the first and have been more likely to ratify the Convention on the Elimination of All Forms of Discrimination Against Women (Gray et al. 2006). Countries with Protestant majorities enjoyed, for example, gender equality in education (Becker and Woessmann 2008, 2010, Norton and Tomal 2009). ${ }^{6}$ In countries with large Muslim populations, on the other hand, girls are discriminated in the education system (Norton and Tomal 2009, Cooray and Potrafke 2011). Gender earnings inequality is higher in countries with large Muslim populations (Kilby and Scholz 2011). Women's relative status as measured by a composite indicator capturing institutional arrangements that are liable to influence, for example, females' labor-market prospects is also impaired in countries with Muslim majorities (see Potrafke and Ursprung 2012 who use the new Social Institutions and Gender Index compiled by Branisa et al. 2009). The Islamic Al-Azhar's constitution has been shown to explicitly discriminate against women (Gouda 2013). Discrimination is especially severe in the Middle East. "Most governments in the Middle East have now formally endorsed, with reservations, the Convention on the Elimination of All Forms of Discrimination against Women (CEDAW)... Yet the Arab Human Development Report documents that the region has some of the high rates of female illiteracy and the lowest rate of female labor force participation in the world. Women in the region encounter serious problems of basic health care, educational access, and income poverty, as well as suffering from exposure to violence, limited legal rights, and lack of access to justice" (Norris 2009a: 2). Women in the Middle East are underrepresented in the workforce and in government. The discrimination against women notwithstanding, experts disagree whether it is oil

\footnotetext{
${ }^{6}$ Countries with a high share of protestants have high income per capita and a high education level (e.g. Becker and Woessmann 2010, Hillman 2009: 524f., 535f.).
} 
or Islam that drives gender inequality (Tripp 2009, Charrad 2009, Norris 2009b, Kang, 2009, Caraway 2009, Ross 2008, 2009a, 2012a, and Groh and Rothschild 2012).

The influence of religious creeds on gender equality is ambiguous: Seguino (2011) uses World Value Surveys data and finds that no religion stands out as more gender-inequitable than others. Norris (2009a and 2011) and Guiso et al. (2003) who also use World Value Surveys data do however find that religion influences attitudes towards gender equality and that support for gender equality is lowest in countries with Muslim majorities.

A straightforward hypothesis is that discrimination against girls and women in countries with large Muslim populations is likely to exist in tandem with disregard for anti-trafficking policies. The reason is that victims of human trafficking are usually women who are forced into prostitution (Di Tommaso et al. 2009, Bettio and Nandi 2010, Omar Mahmoud and Trebesch 2010, Cho et al. 2013b, Nautz and Sauer 2008). ${ }^{7}$ Indeed, human trafficking is "a form of extreme exploitations for sexual and labor purposes and the vast majority of victims are marginalized foreign women (UNODC 2006).” (Cho 2013: 3). ${ }^{8}$

\subsection{Religion and hierarchies between sexes}

Islam has been described having a hierarchical and authoritarian character. Bennett (2010: 35) referring to Mawdudi's Purdah and the Status of Women in Islam which was first published in 1939 ( $2^{\text {nd }}$ edition in 1972) describes, for example, the relationship between men and women in Islam as follows: "Islam recognizes man as naturally stronger than women, so God raised men a "rank" above women for the latter's protection and maintenance, distinguishing their roles. Men are suited to lead, women to nurture. Consequently, their rights are similar but different (Qurán

\footnotetext{
${ }^{7}$ Muslim dominated origin countries had low human trafficking outflows indicating that "female mobility is discouraged in Islamic countries which have presumably more conservative attitudes towards women" (Cho 2012: 18). In a similar vein, the results by Rao and Presenti (2012) show that human trafficking is not more likely in countries with greater gender equality.

${ }^{8}$ Religion and political institutions also affect attitudes to child labor and the prevalence thereof. Maffei et al. (2006) find that more repressive political regimes are more permissive of child labor. On rights of the child and Convention on the Rights of the Child and Basic Immunization, see Gauri (2011).
} 
2:228)". ${ }^{9}$ Islam is also associated with polygamy. Mawdudi insists that Qurán 4:3 gives men permission to marry up to four wives. Men are allowed to marry a Jewish or a Christian wife, while women are only allowed to marry Muslims. ${ }^{10}$ Others disagree that Islam discriminates by gender (Fadel 2012). ${ }^{11}$

Catholicism also used to have a hierarchical and authoritarian character. Women, for example, are still not allowed to become priests. Guiso et al. (2003: 265 ff.) show however that Catholic values have changed after the Second Vatican Council in 1962: Catholics became much more tolerant. As compared to Islam, Catholicism does not insist so much on natural differences between men and women. Protestantism has not have got any hierarchical and authoritarian character. By contrast, Protestant values are fairness and diligence (Weber 1905). Overall Christian values are far less associated with gender issues than Islam.

The model by Inglehart and Norris (2003), Norris and Inglehart (2003) and Norris and Inglehart (2004) "suggests that long-standing religious traditions in each society have a deep and enduring impact upon contemporary social values and moral attitudes, including support for gender equality in politics, as well as shaping broader attitudes towards sexual liberalization” (Norris 2011: 6).

\subsection{Religion and political institutions}

Religion has been shown to influence political institutions. ${ }^{12}$ Many empirical studies show that countries with Muslim majorities enjoy less freedom and are less democratic than countries in which Muslims are a minority (Lipset 1994; Midlarsky 1998; Barro 1999; Karatnycky 2002; Fish

\footnotetext{
${ }^{9}$ Hillman (2004) has described Nietzschean behaviour as the strong being unconstrained by ethics in actions toward the weak. With women naturally physically weaker than men, women in Nietzschean societies are victims of male domination.

${ }^{10}$ To be sure, Bennett (2010) does not hold the view that "Muslim women are equal but different" and shows for the Muslim countries Bangladesh, Indonesia, Pakistan and Turkey that women served as state leaders promoting gender equality.

${ }^{11}$ On Islamist feminism see Halverson and Way (2011).

${ }^{12}$ Facchini (2010) shows that Islam and institutions of freedom are negatively related. Coşgel et al. (2009) elaborate on the nexus between legal constraints and economic power of rulers in Islamic history. On economic performance in Islamic countries, see also Hillman (2007a). For an overview of the relation between democracy and economic development, see Hillman (2007b).
} 
2002; Ross 2001, 2009b, 2012b; Donno and Russett 2004; Borooah and Paldam 2007; Rowley and Smith 2009, Kalyvitis and Vlachaki 2012; Potrafke 2012, 2013).

Correspondingly, Voigt (2005) shows that the presence of Islam is inimical to property rightsprotection, the rule of law, and constitutional democracy. Timur Kuran's momentous studies show how Islam inhibited economic development (Kuran 1997, 2005 and 2011; Kuran and Lustig 2012, Kuran and Singh 2013). Islamic institutions that helped to delay economic modernization in the Middle East encompass many facets (Kuran 2011: 287ff.). In Islam's first few decades, Kuran identifies the inheritance system, the acceptance of polygyny, the Ban on riba , the absence of corporation, the choice of law limited to non-Muslims, the prohibition of apostasy, and the absence of merchant organizations. Institutions that delayed economic modernization have developed after Islam adopted the contract law, the waqfs, the court system, and capitulations. The Middle East's institutional history also curtails its present economic performance (Kuran 2011: 293 ff.). One obstacle to full modernization includes "political systems with low capacity for innovation and experimentation". Kuran (2011: 294) identifies "the weaknesses of private sectors and civil societies, which are rooted in the region's institutional history, breed complacency toward autocratic rule" as historical legacies. By contrast, the results by Woodberry (2012) show that conversionary Protestants promoted the rise of democracy a great deal. Attributes of democracy that conversionary Protestants initiated include: mass printing, newspapers, mass education, civil society and colonial rule of law.

\subsection{Hypotheses}

To investigate how religion influences anti-trafficking policies through political institutions, I adapt the theoretical framework of Berggren and Bjørnskov (2013) as illustrated in Figure $1 .{ }^{13}$ First, depending on institutions, religion directly influences politicians who design anti-trafficking policies. Second, religion influences the expressive behavior of the population at large and interest

\footnotetext{
${ }^{13}$ On behavior and religion, see Berggren (1997). On religion and social trust see Berggren and Bjørnskov (2011).
} 
groups, to which politicians respond. With different institutions reflecting social customs and attitudes to women, political decision making and the implementation of anti-trafficking policies thus differ across political systems. In democracies, politicians (the governing parties, members of parliament) will be more responsive to median voter attitudes in implementing anti-trafficking policies. In autocracies, dictators abide by the customs and follow the preferences of the elites that support the regime. Voters and politicians are likely to care about human trafficking not only because of moral issues and human right concerns, but also because human trafficking is associated with larger shadow economies and, as a consequence, more corruption and lower economic growth (e.g., Belser 2005).

Figure 1. Influence of religion and political institutions on Anti-trafficking policies

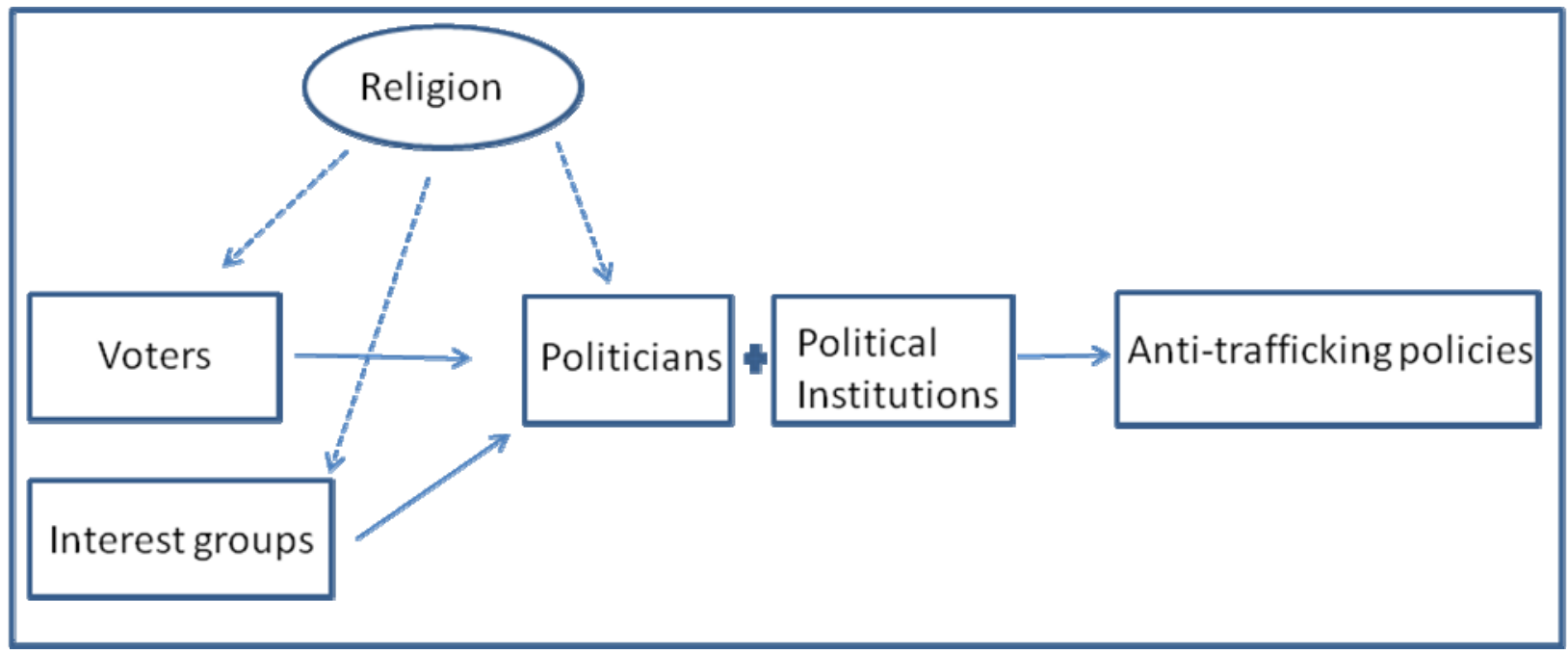

Source: adapted from Berggren and Bjørnskov (2013).

Against the background of the differences between countries with Muslim and Christian majorities, and differences between political systems such as democracies and dictatorships, religion and political institutions are predicted to influence anti-trafficking policies. The hypotheses to be tested are (see also Box 1): 
H1: Anti-trafficking policies are more likely to be present in countries with Christian than with Muslim majorities.

H2: Political institutions enhance/mitigate the influence of religion on anti-trafficking policies: countries have more effective anti-trafficking policies when they are democracies.

Box 1. Strength of Anti-trafficking policies

\begin{tabular}{l|cc}
\hline & Democracy & Dictatorship \\
\hline Christian majority & + & $?$ \\
Muslim majority & $?$ & - \\
\hline
\end{tabular}

\section{Data}

\subsection{The Anti-Trafficking Policy Index}

To measure Anti-trafficking policies, I use the novel Anti-Trafficking Policy Index by Cho et al. (2013a). This index provides data for up to 185 countries over the period 2000-2010. My sample contains only 175 countries because the religion or democracy variables are not available for 7 countries. ${ }^{14}$ The latest version of the Anti-Trafficking Policy Index includes for three countries data for the year 2010 only. The index is coded to reflect policies in three different dimensions: (i) prosecuting (criminalizing) traffickers, (ii) protecting victims, and (iii) preventing human trafficking. The index is based on "raw data derived from two reports on human trafficking, the Annual Report of Trafficking in Persons (United States State Department, 2001-2010) and the Report on Trafficking in Persons: Global Patterns (United Nations Office on Drugs and Crime, 2006 and 2009)" (Cho et al. 2013a: 7). Compliance with these requirements is individually evaluated and measured by three sub indices called "prosecution", "protection" and "prevention"

\footnotetext{
${ }^{14}$ I cannot include Hong Kong, Kosovo, Macau, Micronesia, Netherlands Antilles, Palau, and Timor Leste.
} 
policy - the three prime dimensions of anti-trafficking policy. The "prosecution" sub index “measures the level of governments' efforts to punish and prosecute traffickers and other related offenders (such as employers of trafficking victims, law enforcement officials who collude with traffickers, and clients of services provided by human trafficking victims)" (Cho et al. 2013a: 7). The "protection" sub index "assesses the level of governmental efforts to protect and assist the victims of human trafficking" (Cho et al. 2013a: 8). The "prevention" sub index "evaluates the level of governmental efforts to prevent and combat human trafficking" (Cho et al. 2013a: 9). I list the criteria for the three sub indices in Table A1. For a more encompassing description on the antihuman trafficking indices see Cho et al. (2013a). All three sub indices assume values on a five point scale between 1 (lowest value of strictness) and 5 (highest value of strictness). The overall anti-trafficking policy index is computed as the unweighted sum of the three sub indicators and thus assumes values between 3 (softest anti-trafficking policies) and 15 (strictest anti-trafficking policies).

I use the averages of the overall index and the three sub indices over the period 2000-2010 in every individual country, because I investigate the influence of religion on anti-trafficking policies, and religious majorities do not vary over that period. The data show that governments in developed countries implemented stronger anti-trafficking policies than governments in developing countries. Anti-trafficking policies were strong in countries such as Belgium (14.5), Germany (14.6), Norway (14.3) and the United States (15) and low in countries such as North Korea (3), Somalia (3.2), Iraq (4.0) and Eritrea (4).

The worldwide average score of the overall $3 \mathrm{P}$ index is 9.04 . The worldwide average score of the prosecution sub index is 3.35 , of the protection sub index 2.64 and of the prevention sub index 3.05. The level of compliance with the UN requirements thus differs across the three policy fields. These patterns show that "in terms of compliance with anti-trafficking policy, countries take the "justice and prevention" aspect of the crime more seriously, than the human rights aspect, as 
pointed out by Simmons and Lloyd (2010)" (Cho et al. 2013a: 10). Table A2 shows the correlations between the overall 3P, and its sub indices on prosecution, protection and prevention policies.

\subsection{Religion and democracy}

I use the data on religious fractionalization by Parker (1997). This database reports for each country over the percentage of the population belonging to the most widespread religions in the world. Countries with Muslim majorities are, for example, Algeria (99\%), Iran (98\%), Iraq (94\%), and the Maldives (100\%). The average Muslim share in the sample is $25.57 \%$. Countries with Christian majorities are, for example, Argentina (95\%), Honduras (98\%), and Luxembourg (93\%). The average Christianity share in the sample is $51.59 \% .{ }^{15}$ The average shares for Buddhism are $3.59 \%$, for Hinduism $2.36 \%$ and for traditional religions $5.60 \%$. Israel is the only country with a Jewish majority. I therefore do not include a Jewish variable because it would basically be a dummy variable for Israel. Following the related empirical studies on religion, I consider Islam, Christianity, Buddhism, Hinduism and traditional religions as the five major religion variables and consider the other religions/categories by the variable "other". These data reveal that Islam and Christianity are the most widespread religions around the world. I therefore focus my discussion on the difference between Islam and Christianity. For robustness checks I also measure religion with dummy variables that take on the value one when a particular religion is dominant in a country. The information is from the CIA World Factbook (2013).

I use the Democracy-Dictatorship dummy variable by Cheibub et al. (2010) which has been used in several empirical studies (e.g. Rode and Gwartney 2012, Berdiev et al. 2012, Kalyvitis and Vlachaki 2012). The more traditional measures of democracy were the POLITY IV and the Freedom House indices. These indices have, however, been criticized on several grounds (Munk and Verkuilen 2002, Vreeland 2008, Cheibub et al. 2010). Criticisms include that the previous indices have been based on subjective evaluations and inadequate operational rules and that the

\footnotetext{
${ }^{15}$ I acknowledge, of course, that a high a share of an individual religion in a country does not necessarily imply high religiosity. I elaborate on the influence of religiosity on human anti-trafficking policies in section 5.2.
} 
middle categories are hardly useful to distinguish between political regimes. The DemocracyDictatorship variable by Cheibub et al. (2010) distinguishes between regimes in which executive and legislative offices are allocated in contested elections and those regimes in which this is not the case. The variable assumes the value one for democracies and zero otherwise. The data by Cheibub et al. (2010) are available till 2008 and I therefore use the average democracy score over the period 2000-2008 which assume values between 0 and 1 . There are 89 countries in the sample that have been assigned to be entirely democratic and 69 countries that have been assigned to be entirely autocratic over the period 2000-2008. Countries shifting between democracy and autocracy have been, for example, Burundi (0.4), Georgia (0.5), Nepal (0.4), and Thailand (0.8). For robustness checks I also measure political institutions with the POLITY IV index, the "constraints on the chief executive" sub index (POLITY IV) and the more expansionary (type 2) coding by Cheibub et al. (2010).

\subsection{Correlations}

To illustrate the association between anti-trafficking policies, religion and democracy, I first present correlations between the overall anti-trafficking policy index, Muslim and Christian majorities, and democracy, and second between the overall anti-trafficking policy index and the interaction of Muslim and Christian majorities and democracy. Figures 2 and 3 show that antitrafficking policies are positively associated with the Christians share and negatively with the Muslim share. The correlation coefficient between the Anti-Trafficking Policy Index and Christians share is 0.38 , and -0.43 between the Anti-Trafficking Policy Index and the Muslim share. Figure 4 shows that anti-trafficking policies are positively associated with democracy; the correlation coefficient between the Anti-Trafficking Policy Index and democracy is 0.56 . The influence of religion on anti-trafficking policies appears to be enhanced by democracy: Figure 5 shows that the Christians share is more positively correlated with anti-trafficking policies when a country is democratic. By contrast, the Muslim share appears to be positively correlated with anti-trafficking 
policies only in democracies (Figure 6). Table A3 lists all countries included and the individual values of the share of Christians, Muslims and the democracy score.

Figure 2: Overall Anti-Trafficking Index and Christians share variable.

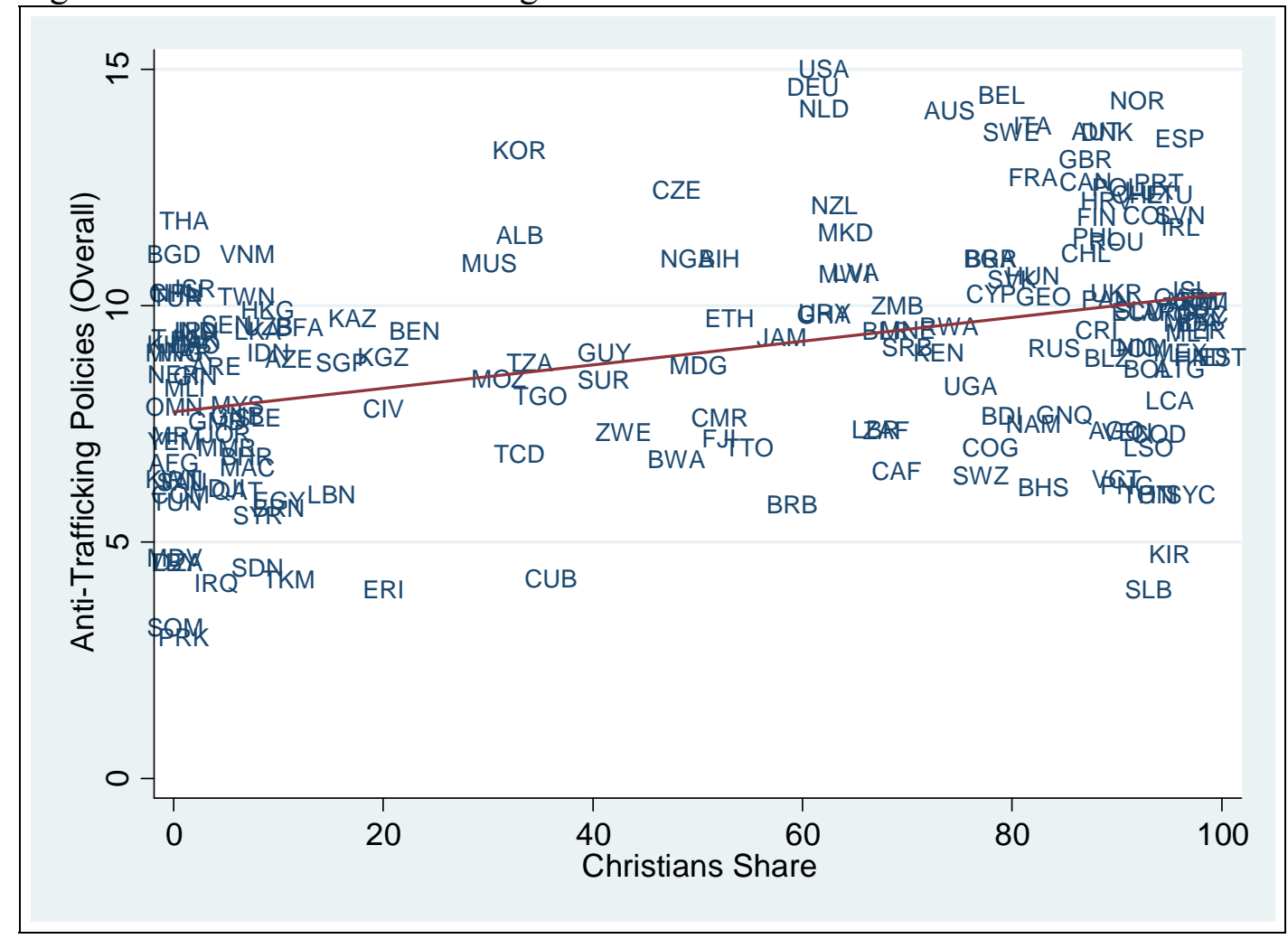

Correlation coefficient: 0.38. Source: Cho et al. (2013a) and Parker (1997).

Figure 3: Overall Anti-Trafficking Index and Muslim share variable.

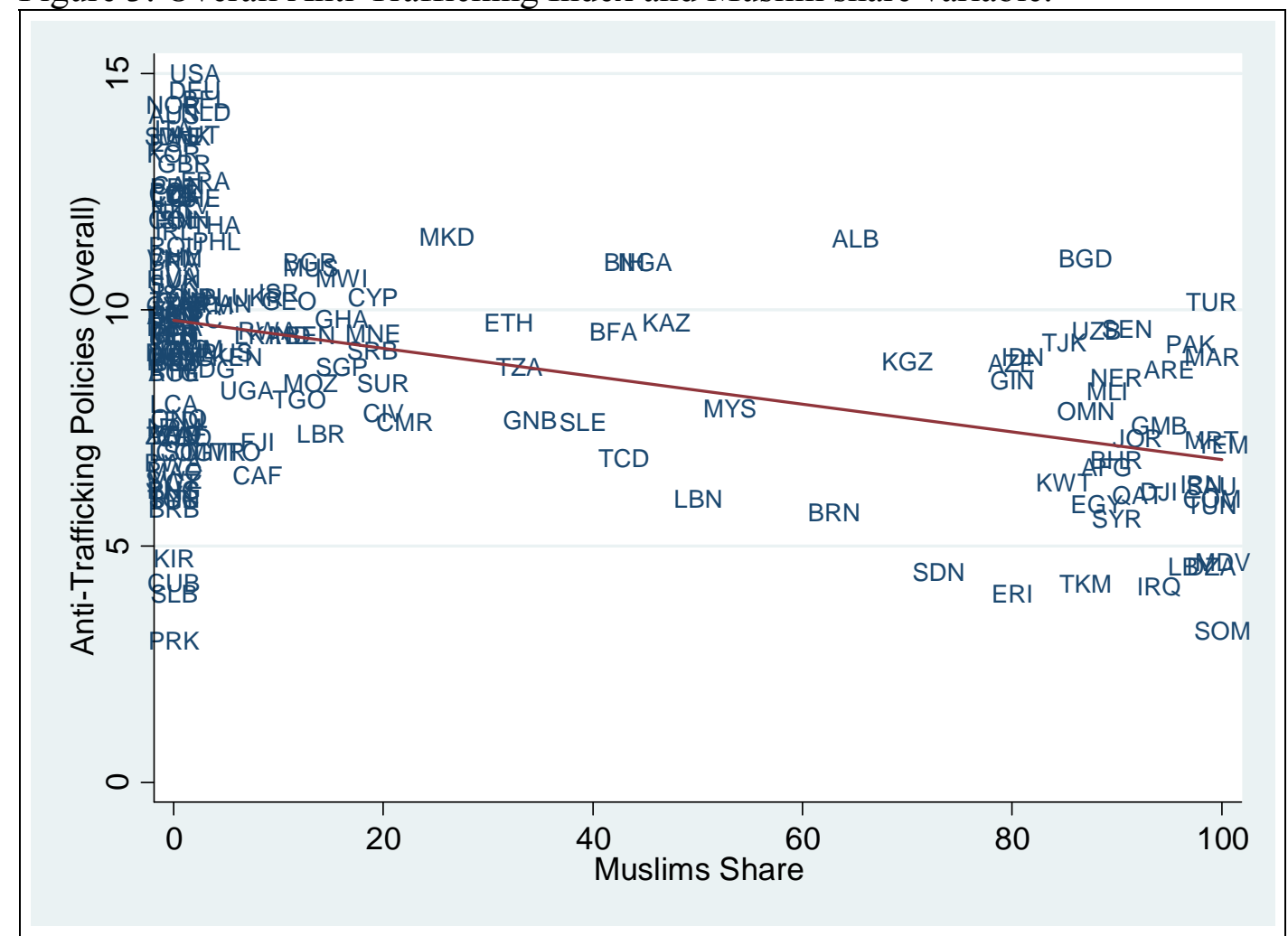

Correlation coefficient: -0.43. Source: Cho et al. (2013a) and Parker (1997). 
Figure 4: Overall Anti-Trafficking Index and democracy variable.

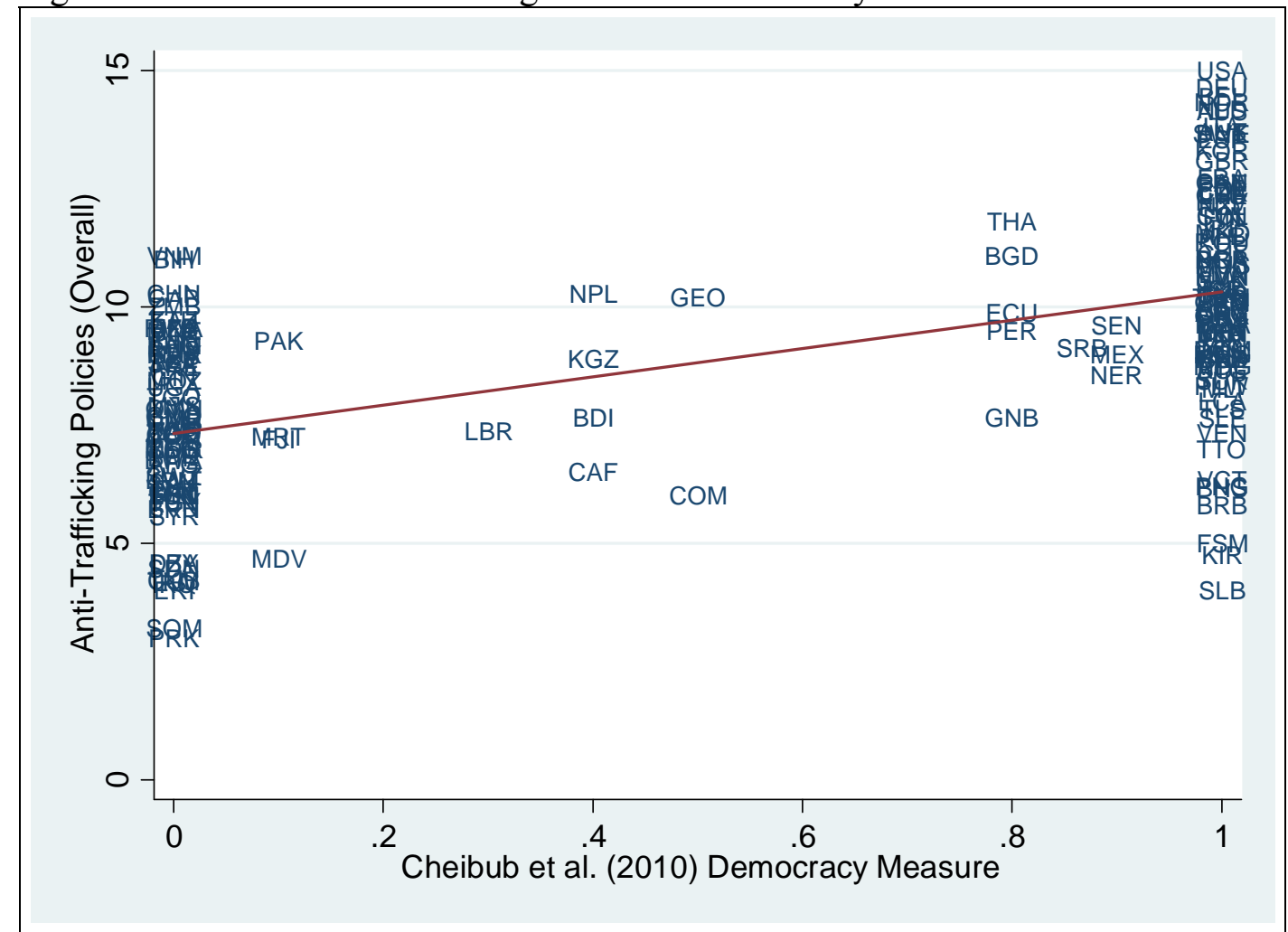

Correlation coefficient: 0.56. Source: Cho et al. (2013a) and Parker (1997).

Figure 5: Overall Anti-Trafficking Index and interaction between Christianity share and democracy variable.

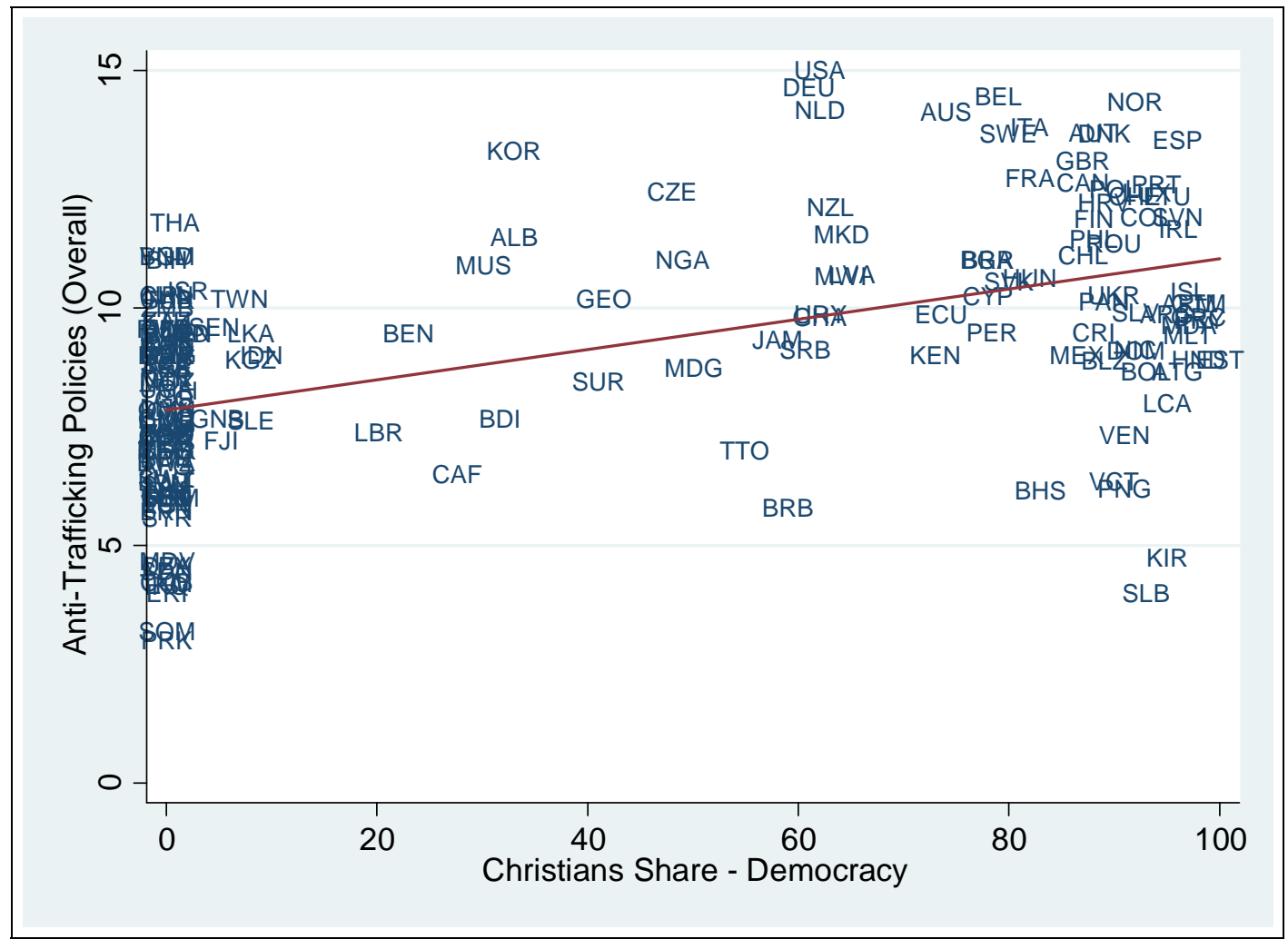

Correlation coefficient: 0.51. Source: Cho et al. (2013a) and Parker (1997). 
Figure 6: Overall Anti-Trafficking Index and interaction between Islam share and democracy variable.

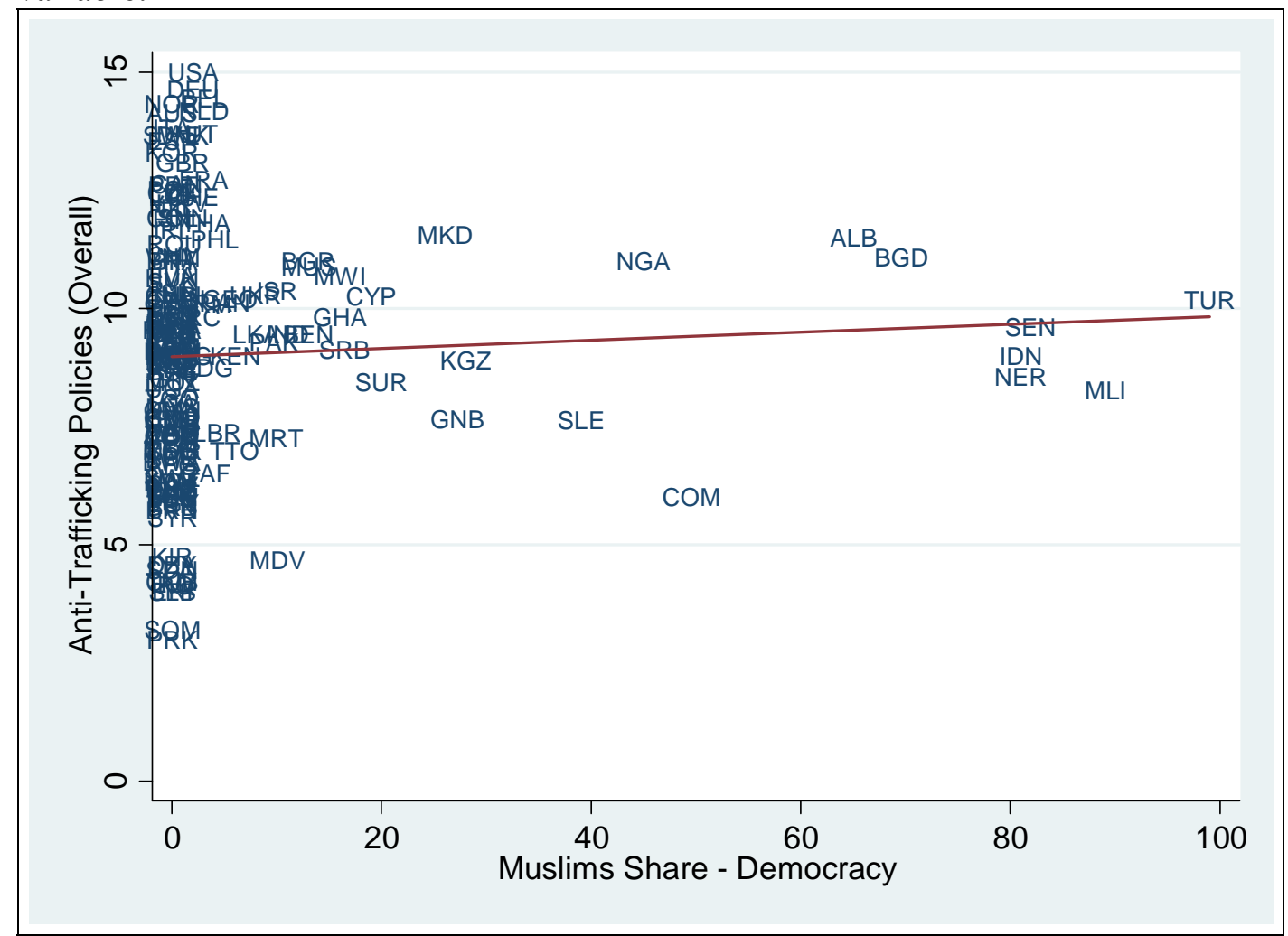

Correlation coefficient: 0.06. Source: Cho et al. (2013a) and Parker (1997).

The correlations between the sub indices for prosecution, protection and prevention reveal similar patterns: the correlation between the religion variables is weakest with the prosecution sub index and strongest with the protection sub index. The correlation between the democracy variable is weakest with the prosecution sub index and strongest with the protection sub index.

\section{The empirical model}

The basic econometric model has the following form:

$$
\begin{gathered}
\text { Anti-trafficking Index } \mathrm{ij}_{\mathrm{ij}}=\Sigma_{k} \alpha_{j k} \text { Religion }_{i k}+\beta_{j} \text { Democracy }_{i}+\Sigma_{k} \gamma_{j k} \text { Religion }_{i k} * \text { Democracy }_{i} \\
+\Sigma_{l} \delta_{j l} \text { Continent }_{i l}+\Sigma_{m} \varepsilon_{j m} \text { Legal Origin }_{i m}+\Sigma_{n} \zeta_{j n} x_{i n}+u_{i j}
\end{gathered}
$$

$$
\text { with } \mathrm{i}=1, \ldots, 175 ; j=1, . ., 4 ; \mathrm{k}=1, \ldots, 5 ; 1=1, \ldots, 4 ; \mathrm{m}=1, \ldots, 4 ; \mathrm{n}=1, \ldots, 6
$$


The dependent variable Anti-trafficking Index $i j$ associates anti-trafficking policies in country $i$ for

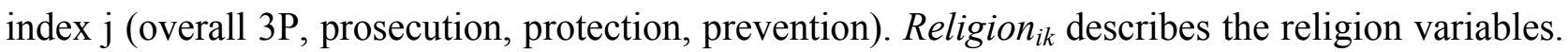
I distinguish between the shares of Christians (reference category), Muslims, Buddhists, Hindus, Traditional Religions and others. Democracy $y_{i}$ is the democracy variable. Religion $_{i k} *$ Democracy $_{i}$ is the interaction term between the religion and democracy variables. I include the interaction term to test whether political institutions have mitigated/enhanced the influence of religion types on antitrafficking policies. Continent ${ }_{i l}$ are continental dummy variables assuming the value one if country i belongs to continent $l$ and zero otherwise. I distinguish between five different continents: Africa

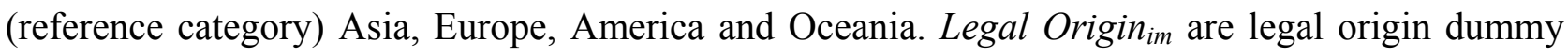
variables (La Porta et al. 1999). I distinguish between five different legal origins: British (reference category), French, German, Scandinavian and Socialist. ${ }^{16}$ Table A4 shows descriptive statistics of all variables. The vector $\boldsymbol{x}_{i}$ contains the economic control variables. Following Cho et al. (2013a) I include the logarithm of per capita GDP, the logarithm of total population, an OECD dummy variable, the women's economic rights indicator (Cingranelli and Richards 2010), absence of corruption (CPI index by Transparency International) and an oil production value ${ }^{17} \cdot{ }^{18}$ All these variables refer to the average of the annual data over the period 2000-2010.

I estimate the model with ordinary least squares (OLS) and robust standard errors.

\footnotetext{
${ }^{16}$ I acknowledge that Scandinavian legal origin is associated with a larger welfare state and higher levels of social trust (Bergh and Bjørnskov 2011).

${ }^{17}$ I use the data on oil production by the U.S. Energy Information Administration (EIA). To compute a nominal oil production value (per capita), I use the following formula: [EIA crude oil production (1000 barrels per day)*365*crude oil spot price (US\$ per barrel)*1000]/Population. I measure the crude oil spot price as the average of the Brent spot price (US\$ per barrel) and the West Texas Intermediate spot price (US\$ per barrel) as provided by the EIA. I convert the nominal oil production value into real terms (constant 2000 US\$) by using the US GDP deflator as employed by Michael L. Ross. I use populations reported in the World Bank's World Development Indicators.

${ }^{18}$ In section 2, I hypothesize that religion influences women's rights. For example, women's rights are less pronounced in countries with Muslim majorities. The religion variables are thus likely to be correlated with the women's rights variable. For example, the correlation coefficient between the Muslim share variable and the women's rights variable is -0.45. Inferences regarding the religion and political institutions variables do not change when the women's rights variable is excluded. In a similar vein, the influence of the women's rights dramatically decreases when I estimate the model only for countries with non-Muslim majorities. I have included the women's rights to avoid potential concerns about omitted variable bias.
} 


\section{Results}

\subsection{Basic results}

Table 1 shows the regression results for the overall 3P index. The control variables display the expected signs and are statistically significant in several cases. The coefficients of the socialist legal origin variable is statistically significant at the 5\% level in columns (2) and (3) and indicate that anti-trafficking policies are stronger in countries with a socialist legacy as compared to countries with a British legal origin. This finding is plausible because, first, many former socialist countries are major sources of human trafficking outflows and, second, countries with socialist legacy have promoted gender equality. The coefficients of the other legal origin variables and the regional dummy variables do not turn out to be statistically significant. Per capita income does not turn out to be statistically significant. This finding corresponds with the results by Cho et al. (2013a). The coefficient of the population size variable is statistically significant at the $1 \%$ level and has a positive sign. This estimate indicates that the overall 3P Index is in a given country by some 0.45 points higher than in an otherwise similar country if it has a $1 \%$ bigger population. The coefficients of the women's economic rights variable have the expected positive sign but do not turn out to be statistically significant. The coefficient of the OECD variable has the expected positive sign and is statistically significant at the $10 \%$ level in column (4). The CPI index measuring the absence of corruption has the expected positive sign and is statistically significant at the $1 \%$ level. The estimate indicates that the overall $3 \mathrm{P}$ index is about 0.37 points higher when the CPI increases by one point (on a scale from 1 to 10 ), or that the overall $3 \mathrm{P}$ index is about 0.8 points higher when the CPI increases by one standard deviation. The finding that corruption mitigates anti-trafficking policies is also in line with the empirical findings by Cho et al. (2013a). The oil production variable does not turn out to be statistically significant.

The results reported in Table 1 show that types of religion and political institutions have influenced anti-trafficking policies: democracies had stronger anti-trafficking policies than dictatorships. The coefficient of the democracy variable is statistically significant at the $1 \%$ level in 
column (1) and at the $10 \%$ level in columns (2) and (4). The coefficients of the Buddhists, Traditional Religions and other religion variables mostly do not turn out to be statistically significant (except the coefficient of the others variable in columns 2 and 3). The coefficient of the Hinduism variable is statistically significant at the 5\% level in columns (1) and (2). The results in column (3) show however that the effect of the Hindus variable is driven by India. By contrast the coefficient of the Islam variable is statistically significant at the 5\% level in column (1) and at the $1 \%$ level in columns (2) to (4). The coefficient has a negative sign which indicates that countries with Muslim majorities had less strict anti-trafficking policies than countries with Christian majorities (reference category). Because the results in columns (1) to (3) show that significant differences in policies against human trafficking only occur between countries with Christian and Muslim majorities, column (4) shows results where I have combined Buddhists, Hindus, Traditional Religions and the previous other variable in one new group. Inferences do not change at all. 
Table 1: Regression Results. Dependent variable: 3P Anti-trafficking Index OLS with robust standard errors. Religious reference: Christianity

\begin{tabular}{|c|c|c|c|c|}
\hline & $(1)$ & $(2)$ & $(3)$ & $(4)$ \\
\hline & Types of religion & Types of religion & Excluding India & Muslim/Christian \\
\hline Muslims & $\begin{array}{c}-0.0124 * * \\
(-2.09)\end{array}$ & $\begin{array}{c}-0.0197 * * * \\
(-2.90)\end{array}$ & $\begin{array}{c}-0.0204 * * * \\
(-2.95)\end{array}$ & $\begin{array}{c}-0.0192 * * * \\
(-2.93)\end{array}$ \\
\hline Buddhists & $\begin{array}{c}0.0164 \\
(1.41)\end{array}$ & $\begin{array}{c}0.00584 \\
(0.51)\end{array}$ & $\begin{array}{c}0.00403 \\
(0.35)\end{array}$ & \\
\hline Hindus & $\begin{array}{c}0.0294 * * \\
(1.98)\end{array}$ & $\begin{array}{c}0.0422 * * \\
(2.20)\end{array}$ & $\begin{array}{l}0.0295 \\
(1.20)\end{array}$ & \\
\hline Traditional Religions & $\begin{array}{c}0.00601 \\
(0.41)\end{array}$ & $\begin{array}{c}0.00268 \\
(0.20)\end{array}$ & $\begin{array}{c}0.00209 \\
(0.15)\end{array}$ & \\
\hline Others & $\begin{array}{c}-0.00271 \\
(-0.12)\end{array}$ & $\begin{array}{c}-0.0261^{*} \\
(-1.66)\end{array}$ & $\begin{array}{c}-0.0282^{*} \\
(-1.80)\end{array}$ & \\
\hline Others (including Buddhists etc.) & & & & $\begin{array}{c}-0.00225 \\
(-0.26)\end{array}$ \\
\hline Democracy (Cheibub et al. 2010) & $\begin{array}{c}2.740 * * * \\
(4.35)\end{array}$ & $\begin{array}{l}1.151^{*} \\
(1.71)\end{array}$ & $\begin{array}{l}0.996 \\
(1.46)\end{array}$ & $\begin{array}{l}1.161^{*} \\
(1.73)\end{array}$ \\
\hline Muslims*Democracy & $\begin{array}{c}0.00682 \\
(0.76)\end{array}$ & $\begin{array}{l}0.0168 \\
(1.63)\end{array}$ & $\begin{array}{c}0.0170 \\
(1.65)\end{array}$ & $\begin{array}{l}0.0155 \\
(1.52)\end{array}$ \\
\hline Buddhists*Democracy & $\begin{array}{c}-0.0172 \\
(-0.98)\end{array}$ & $\begin{array}{c}-0.0126 \\
(-0.58)\end{array}$ & $\begin{array}{c}-0.0142 \\
(-0.65)\end{array}$ & \\
\hline Hindus*Democracy & $\begin{array}{c}-0.0466^{* *} \\
(-2.15)\end{array}$ & $\begin{array}{c}-0.0532^{*} \\
(-1.77)\end{array}$ & $\begin{array}{c}-0.0139 \\
(-0.38)\end{array}$ & \\
\hline Traditional Religions *Democracy & $\begin{array}{c}-0.0478 * * \\
(-2.47)\end{array}$ & $\begin{array}{c}-0.0114 \\
(-0.68)\end{array}$ & $\begin{array}{c}-0.00824 \\
(-0.49)\end{array}$ & \\
\hline Other*Democracy & $\begin{array}{l}0.0158 \\
(0.59)\end{array}$ & $\begin{array}{l}0.0225 \\
(1.33)\end{array}$ & $\begin{array}{c}0.0248 \\
(1.47)\end{array}$ & \\
\hline Other (including Buddhism etc.) *Democracy & & & & $\begin{array}{c}-0.00182 \\
(-0.17)\end{array}$ \\
\hline Asia & & $\begin{array}{l}0.340 \\
(0.64)\end{array}$ & $\begin{array}{l}0.468 \\
(0.90)\end{array}$ & $\begin{array}{l}0.543 \\
(1.18)\end{array}$ \\
\hline Europe & & $\begin{array}{l}0.651 \\
(0.90)\end{array}$ & $\begin{array}{l}0.803 \\
(1.15)\end{array}$ & $\begin{array}{l}1.045 \\
(1.56)\end{array}$ \\
\hline America & & $\begin{array}{l}-0.393 \\
(-0.63)\end{array}$ & $\begin{array}{l}-0.299 \\
(-0.49)\end{array}$ & $\begin{array}{l}-0.238 \\
(-0.38)\end{array}$ \\
\hline Oceania & & $\begin{array}{l}-1.116 \\
(-1.30)\end{array}$ & $\begin{array}{l}-0.944 \\
(-1.10)\end{array}$ & $\begin{array}{l}-0.930 \\
(-1.16)\end{array}$ \\
\hline Legal Origin (french) & & $\begin{array}{l}0.337 \\
(1.19)\end{array}$ & $\begin{array}{l}0.288 \\
(1.04)\end{array}$ & $\begin{array}{l}0.243 \\
(0.87)\end{array}$ \\
\hline Legal Origin (socialist) & & $\begin{array}{c}1.200 * * \\
(2.20)\end{array}$ & $\begin{array}{c}1.129 * * \\
(2.12)\end{array}$ & $\begin{array}{l}0.796 \\
(1.51)\end{array}$ \\
\hline Legal Origin (german) & & $\begin{array}{c}0.0696 \\
(0.08)\end{array}$ & $\begin{array}{l}0.0681 \\
(0.08)\end{array}$ & $\begin{array}{l}0.0261 \\
(0.03)\end{array}$ \\
\hline Legal Origin (scandinavian) & & $\begin{array}{l}0.117 \\
(0.16)\end{array}$ & $\begin{array}{l}0.123 \\
(0.17)\end{array}$ & $\begin{array}{c}-0.0787 \\
(-0.11)\end{array}$ \\
\hline log per capita GDP & & $\begin{array}{c}-0.0359 \\
(-0.17)\end{array}$ & $\begin{array}{c}-0.0456 \\
(-0.22)\end{array}$ & $\begin{array}{l}-0.144 \\
(-0.72)\end{array}$ \\
\hline log Population & & $\begin{array}{c}0.485^{* * *} \\
(5.47)\end{array}$ & $\begin{array}{c}0.519^{* * *} \\
(5.71)\end{array}$ & $\begin{array}{c}0.437 * * * \\
(5.12)\end{array}$ \\
\hline OECD & & $\begin{array}{l}0.751 \\
(1.41)\end{array}$ & $\begin{array}{l}0.700 \\
(1.31)\end{array}$ & $\begin{array}{c}0.906^{*} \\
(1.75)\end{array}$ \\
\hline Women's Economic Rights & & $\begin{array}{l}0.254 \\
(0.73)\end{array}$ & $\begin{array}{l}0.290 \\
(0.83)\end{array}$ & $\begin{array}{l}0.369 \\
(1.11)\end{array}$ \\
\hline Absence of corruption & & $\begin{array}{c}0.384 * * * \\
(2.98)\end{array}$ & $\begin{array}{c}0.383^{* * *} \\
(2.98)\end{array}$ & $\begin{array}{c}0.345^{* * *} \\
(2.68)\end{array}$ \\
\hline Oil production value & & $\begin{array}{c}-0.0219 \\
(-0.45)\end{array}$ & $\begin{array}{c}-0.0277 \\
(-0.57)\end{array}$ & $\begin{array}{c}-0.0138 \\
(-0.29)\end{array}$ \\
\hline Constant & $\begin{array}{c}7.750 * * * \\
(15.31)\end{array}$ & $\begin{array}{l}2.501 \\
(1.30)\end{array}$ & $\begin{array}{l}2.316 \\
(1.21)\end{array}$ & $\begin{array}{c}3.713^{* *} \\
(2.09)\end{array}$ \\
\hline Observations & 175 & 168 & 167 & 168 \\
\hline R-squared & 0.408 & 0.735 & 0.740 & 0.719 \\
\hline
\end{tabular}

Notes: Absolute value of t statistics in brackets; * significant at 10\%; ** significant at 5\%; $* * *$ significant at $1 \%$ 
The marginal effects of the religion variables have to be interpreted conditionally on the interaction with the democracy variable (see Friedrich 1982). Figure 7 shows marginal effects of the Muslim share variable as compared to the Christian share variable evaluated at different levels of democracy. There were significant marginal effects describing differences in religious influence in democracies and dictatorships. The marginal effects are statistically significant at the $5 \%$ level when the $95 \%$ confidence interval does not include the zero line. Countries with Muslim majorities thus had significantly laxer policies against human trafficking than countries with Christian majorities when the democracy variable assumes values smaller than 0.6 (on a scale from 0 to 1 for pure dictatorships and pure democracies). In pure dictatorships, for example, the Anti-Trafficking Policy Index decreased by about 0.19 points, when the share of Muslims increased by one point, implying that the Anti-Trafficking Policy Index in a dictatorship with no Muslims is by 1.9 points higher than in an otherwise identical but purely Muslim dictatorship. This marginal effect is statistically significant at the $1 \%$ level. The marginal effect of the Muslim share variable evaluated for pure democracies does however not turn out to be statistically significant indicating that Islam did not mitigate anti-trafficking policies in democracies. ${ }^{19}$

Figure 8 shows the marginal effects of the Muslim share variable for the prosecution sub index: countries with Muslim majorities did not implement different prosecution policies than countries with Christian majorities.

Figure 9 shows the marginal effects of the Muslim share variable for the protection sub index: The results are similar to the overall 3P anti-trafficking index. Countries with Muslim majorities thus had significantly laxer protection policies than countries with Christian majorities when the democracy variable assumes values smaller than 0.7 . In pure dictatorships the protection sub index decreased by about 0.009 points, when the share of Muslims increased by one point, implying that the protection sub index in a dictatorship with no Muslims is by 0.9 points higher (on a scale from

\footnotetext{
${ }^{19}$ These marginal effects are not out-of-sample predictions. Countries with Muslim majorities that have been entirely democratic are, for example, Albania, Indonesia, Senegal, and Turkey.
} 
1 to 5) than in an otherwise identical but purely Muslim dictatorship. This marginal effect is statistically significant at the $1 \%$ level.

Figure 10 shows the marginal effects of the Muslim share variable for the prevention sub index: countries with Muslim majorities thus had significantly laxer prevention policies than countries with Christian majorities when the democracy variable assumes values smaller than 0.8. In pure dictatorships the prevention sub index decreased by about 0.007 points, when the share of Muslims increased by one point, implying that the prevention sub index in a dictatorship with no Muslims is by 0.7 points higher (on a scale from 1 to 5 ) than in an otherwise identical but purely Muslim dictatorship. This marginal effect is statistically significant at the $1 \%$ level.

Figure 7. Marginal effect of the Muslim share as compared to Christian share. Conditioned on democracy. Effects refer to column (4) of Table 1. Overall 3P index.

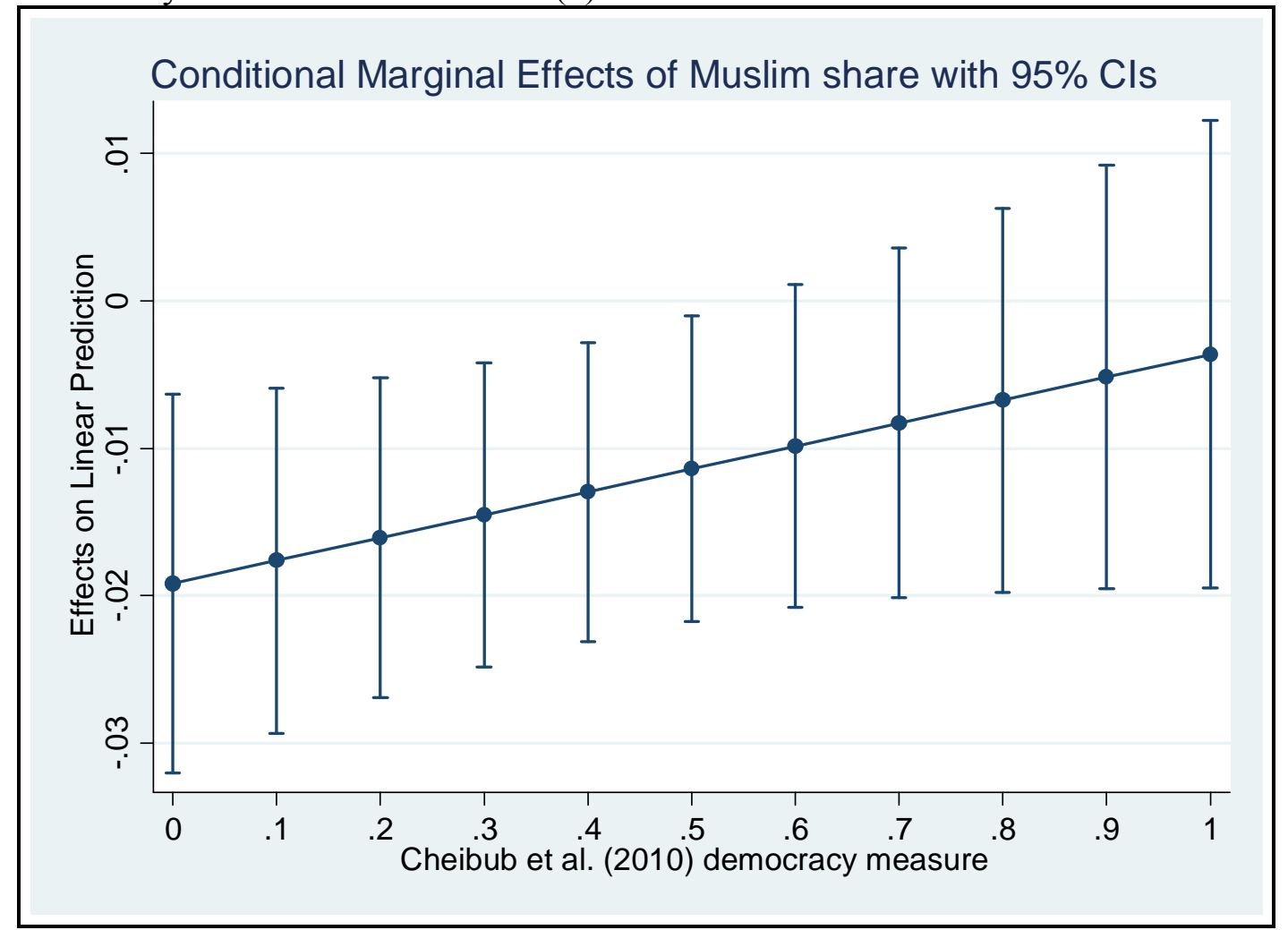


Figure 8. Marginal effect of the Muslim share as compared to Christian share. Conditioned on democracy. Effects refer to a model as in column (4) of Table 1. Prosecution index.

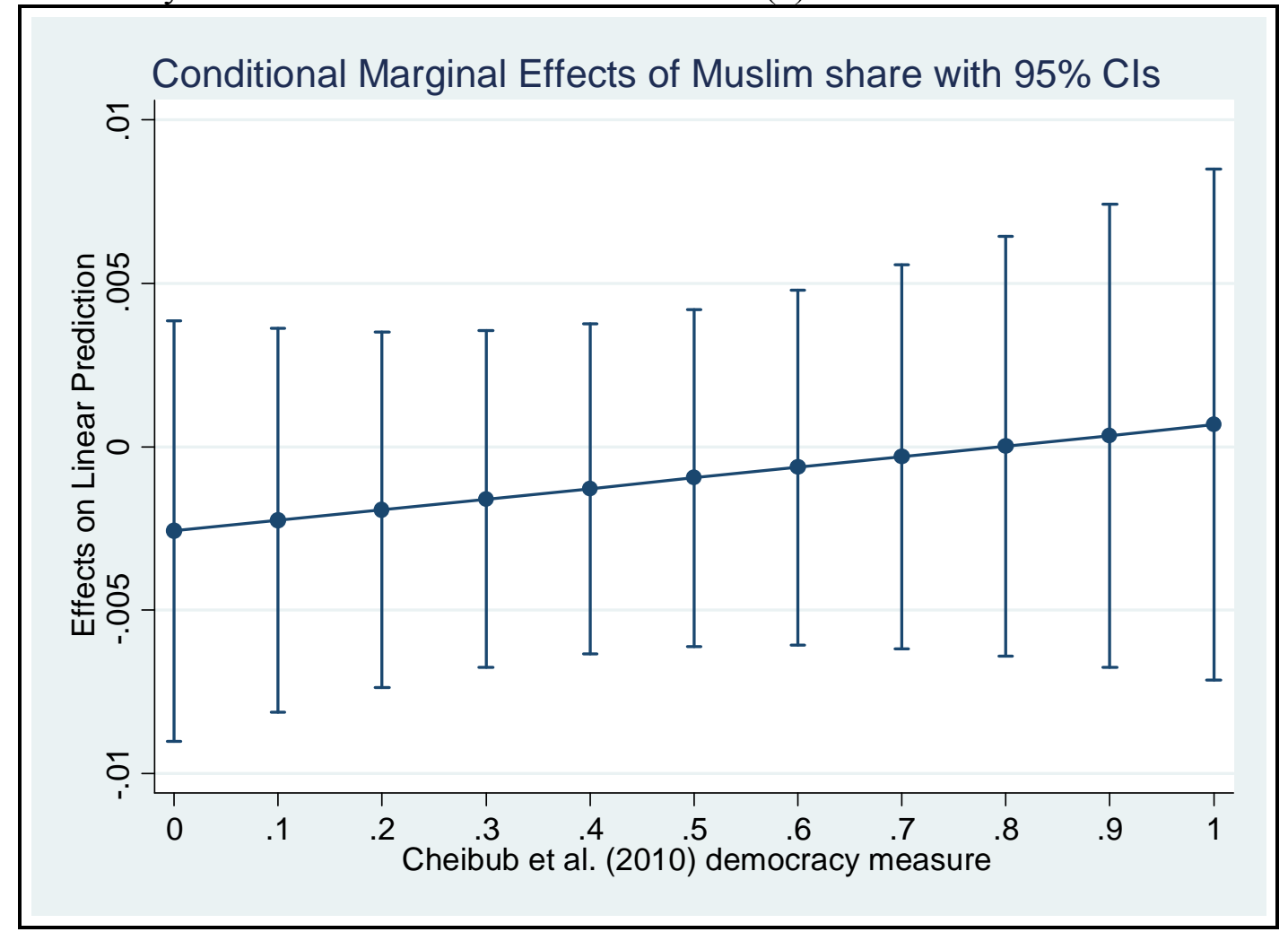

Figure 10. Marginal effect of the Muslim share as compared to Christian share. Conditioned on democracy. Effects refer to a model as in column (4) of Table 1. Protection index.

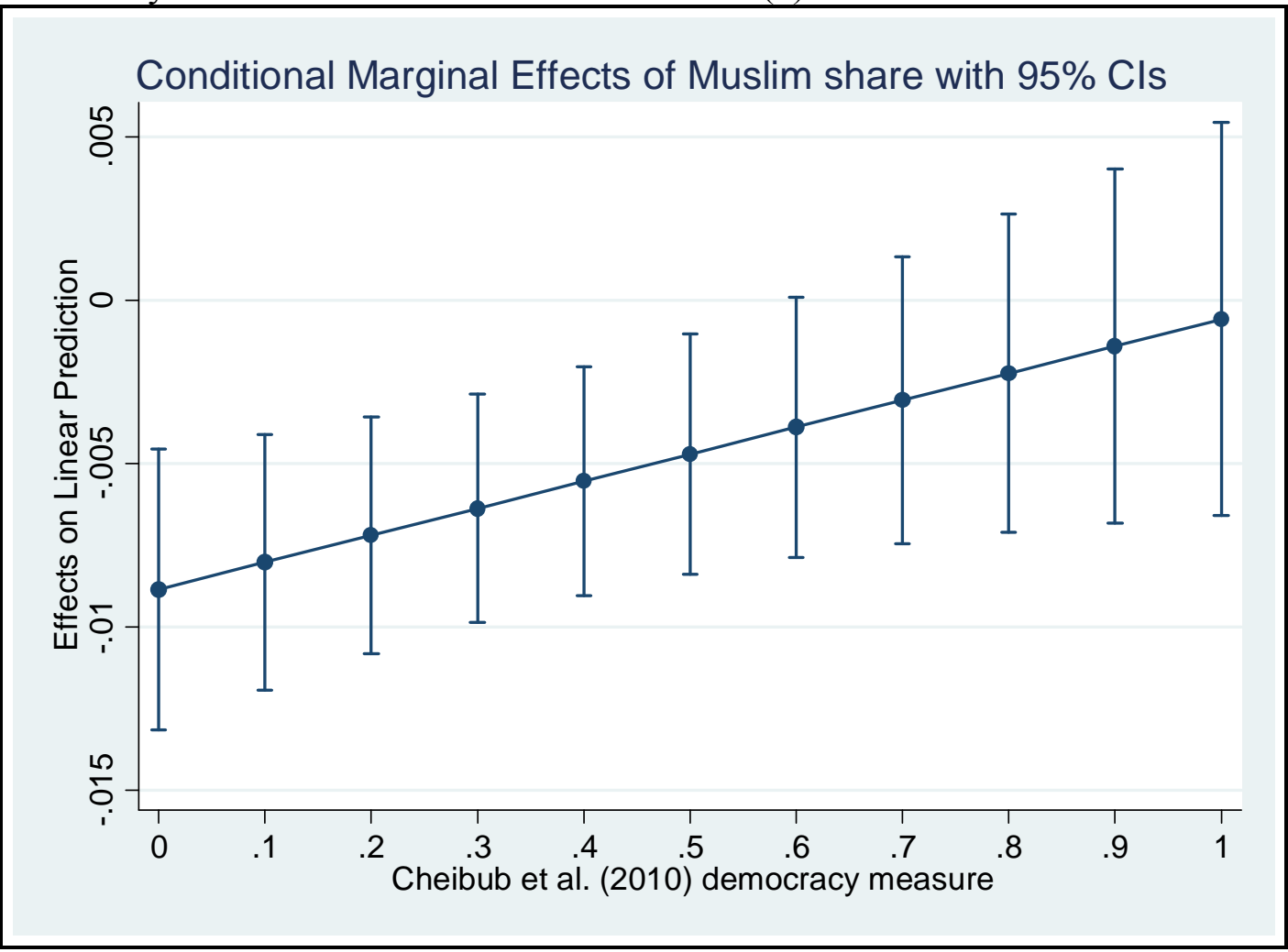


Figure 9. Marginal effect of the Muslim share as compared to Christian share. Conditioned on democracy. Effects refer to a model as in column (4) of Table 1. Prevention index.

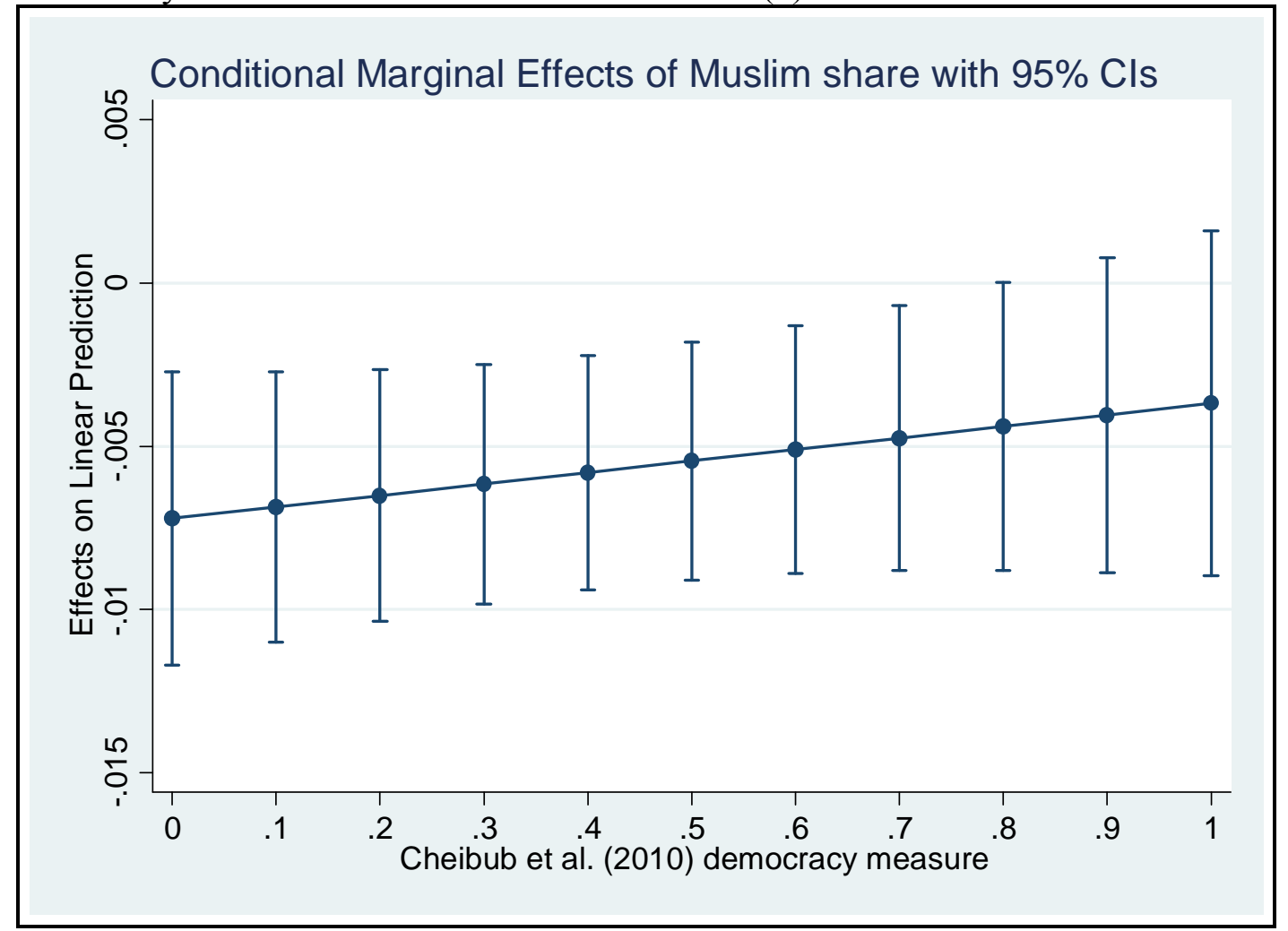

Why is it that religion influences the protection and the prevention sub indices, but does not influence the prosecution index? Cho and Vadlamannati (2012: 252f.) elaborate on strategic decisions governments undertake by adopting or not adopting strict anti-trafficking polices. Governments are likely to select obligations with which they can comply with the lowest cost while satisfying the preferences of major powers in international politics such as the United States. As compared to protection and prevention policies, prosecution policy appears to be most costly to implement. For example, the obligations of prosecution require adopting the newly defined concept of human trafficking in national legislation. By contrast, the obligations of prevention policies do not require adopting new legislations, but rather include anti-trafficking public and media campaigns, and controlling borders, airports and train stations. While protection and prevention policies are less costly than prosecution policies, they may contradict with Islamic values. "Protection policies mainly protect victims, while prosecution policies mainly target the perpetrators" (Cho et al. 2013a: 34). In countries with Muslim majorities, protection appears to be 
very costly in a normative sense because it requires acknowledging human trafficking victims (including prostitutes) as victims and providing assistance for them. It is conceivable that Muslim dominated countries do not want to protect victims of human trafficking which are mostly women and receive expressive utility by not adopting protections and preventions policies (see Hillman 2010 on expressive behavior). These results perfectly correspond with, first, the empirical studies showing that women are discriminated in Muslim dominated countries and, second the study by Berggren and Bjørnskov (2013) showing that religion influences de facto enforcement but not necessarily de jure rules.

\subsection{Robustness checks}

I have checked the robustness of the results in several ways. Countries with Muslim majorities may have laxer policies against human trafficking not because of Islam but rather because Muslims tend to have more intense religious beliefs. To elaborate on this issue, I have included the variable on religiosity by Berggren and Bjørnskov (2013). This variable is based on Gallups World View question how important religion is. The data on religiosity are not available for the entire sample I use, in particular, for several countries with Muslim majorities. The results in Table 2 column (1) show that the religiosity variable does not turn out to be statistically significant, and the Muslim share variable remains statistically significant at the $10 \%$ level.

One may well distinguish between Christian denominations such as Protestants and Catholics and also Sunni and Shia Muslims. I cannot distinguish between Sunni and Shia Muslims by using the data on religion by Parker (1997) and also not by using alternative data on religious fractionalization such as the data by Alesina et al (2003). The category Muslim by Alesina et al. (2003) is for some countries subdivided in Shia Muslim and Sunni Muslim, for other countries this sub-division is not recorded. By using the data by Parker (1997) I can however distinguish between Protestants and Catholics. Columns (2) and (3) in Table 2 show results where I have used Catholics and Protestants as reference category: countries with Protestant and Catholic majorities did not 
implement significantly different policies against human trafficking. By contrast, the Muslim share variable remains statistically significant and indicates that countries with Muslim majorities pursued laxer anti-trafficking policies than both countries with Protestant and Catholic majorities.

I have used the revised combined POLITY IV index as alternative measure for political institutions. The revised combined POLITY IV index assumes values between -10 (pure dictatorship) and 10 (pure democracy). Column (4) in Table 2 shows that inferences regarding the differences between countries with Muslim and Christian majorities do not change. The marginal effects (not shown) reveal that countries with Muslim majorities had significantly laxer antitrafficking policies than countries with Christian majorities when the POLITY IV variable assumes values smaller than 3 .

I have also used the "constraints on the chief executive" sub index (POLITY IV) as an alternative democracy measure (results not shown). This index assumes values between 1 (pure autocracy) to 7 (pure democracy). The marginal effects reveal that countries with Muslim majorities had significantly laxer anti-trafficking policies than countries with Christian majorities when the "constraints on the chief executive" sub index assumes values smaller than 6 . Cheibub et al. (2010) have coded democracy conservatively, i.e. they have coded a country as a democracy only if there has been alternation in power. Some countries appear, however, to have "contested" elections for the executive and legislature, but there has never been an alternation of the government. The alternative coding by Cheibub et al. (2010) considers these cases as democracies. I have included the more expansive democracy coding (results not shown). At an average level of the more expansive democracy coding, inferences do not change. Evaluated at the minimum and maximum level of democracy, inferences do however change: non-democratic and democratic countries with Muslim majorities had less strict policies against human trafficking. The effect of the Muslim share variable slightly fails statistical significance in pure dictatorships. This result is plausible because the more expansive democracy measure classifies many countries to be democratic. 
Table 2: Regression Results. Dependent variable: 3P Anti-trafficking Index OLS with robust standard errors.

(1) (2) (2) Protestants

Muslims

Protestants

Catholics

Others

Democracy (Cheibub et al. 2010)

Democracy (POLITY IV)

Muslims*Democracy (Cheibub)

Protestants*Democracy (Cheibub)

Catholics*Democracy (Cheibub)

Others*Democracy (Cheibub)

Muslims*Democracy (POLITY IV)

Others*Democracy (POLITY IV)

Asia

Europe

America

Oceania

Legal Origin (french)

Legal Origin (socialist)

Legal Origin (german)

Legal Origin (scandinavian)

log per capita GDP

$\log$ Population

OECD

Women's Economic Rights

Absence of corruption

Oil production value

Religiosity

Constant

ligiosity incl.

$-0.0145^{*}$

$(-1.90)$ $-0.0173^{* *}$

$(-2.10)$

0.00277

(0.16)

-0.00120
$(-0.12)$
$1.690^{* *}$
$(2.08)$

(2.21)

0.00146

$(0.16)$

0.00767

$(0.71)$

-0.0234
$(-1.27)$

$-0.00583$

$(-0.51)$

(-$$
0.692
$$

(1.51)

$1.496 * *$

(2.13)

0.216

$(0.33)$

1.564

(1.56)

0.0274

(0.09)

0.933

(1.61)

0.343

(0.43)

0.0546

(0.07)

$-0.301$

$(-1.40)$

$0.345^{* * *}$

(3.61)

$0.875^{*}$

(1.70)

0.265

(0.74)

$0.433 * * *$

(3.02)

$-0.00374$

$(-0.07)$

1.420

(1.50)

4.150*

(1.90)

$$
\begin{gathered}
(-1.27) \\
-0.00497 \\
(-0.42)
\end{gathered}
$$

0.0106

(0.95)

.0234

0.446

(0.94)

0.933

(1.35)

$-0.239$

(-0.39)

$-0.588$

$(-0.83)$

0.0616

(0.21)

0.824

(1.61)

0.196

(0.22)

1.109

(1.32)

$-0.260$

(-1.27)

$0.412 * * *$

(4.93)

$0.946^{*}$

(1.82)

0.328

(0.95)

$0.429 * * *$

(3.27)

0.0185

(0.37)
$4.546^{* *}$

(2.51)

(3)

(4)

Catholics

POLITY IV

$-0.0185^{*}$

$-0.0133^{* *}$

$(-1.80)$

$(-2.26)$

0.00104

(0.08)

$-0.00273$

$(-0.24)$

0.377

(0.44)

$-0.00437$

$(-0.63)$

0.0995

(1.32)

$0.0250^{* *}$

(2.20)

0.0135

(0.96)

0.00777

(0.60)

0.000646

$(0.70)$

$-0.000217$

$(-0.22)$

$0.949^{*}$

(1.76)

1.156

$\begin{array}{ll}(1.49) & (1.54) \\ -0.463 & 0.0923\end{array}$

$\begin{array}{ll}(1.49) & (1.54) \\ -0.463 & 0.0923\end{array}$

$(-0.71) \quad(0.13)$

$\begin{array}{ll}-0.842 & -0.998\end{array}$

$(-1.01) \quad(-1.06)$

$0.0243 \quad 0.141$

$\begin{array}{ll}0.08) & (0.42)\end{array}$

$\begin{array}{ll}0.859 & 0.666\end{array}$

(1.64) (1.23)

$0.0910 \quad 0.0676$

$\begin{array}{ll}(0.11) & (0.08)\end{array}$

$0.620 \quad-0.161$

$(0.83) \quad(-0.22)$

$-0.202 \quad-0.265$

$(-1.03) \quad(-1.08)$

$0.426 * * * \quad 0.332 * * *$

(4.82) (3.21)

$\begin{array}{ll}0.759 & 0.887\end{array}$

(1.44) (1.61)

$0.378 \quad 0.568$

(1.15) (1.51)

$0.374 * * * \quad 0.374 * * *$

(3.02) (2.69)

$0.00337 \quad 0.0239$

$\begin{array}{ll}(0.07) & (0.41)\end{array}$

Observations

148

$4.222 * *$

$5.501 * * *$

(2.14)

R-squared

0.722

0.728

0.728

0.697

Notes: Absolute value of $\mathrm{t}$ statistics in brackets; * significant at $10 \% ; * *$ significant at $5 \%$; ** significant at $1 \%$ 
I have replaced the data on religion by Parker (1997), which report the percentage of the population belonging to the most widespread religions, by religion dummy variables that take on the value one when a particular religion is dominant in a country. The information is from the CIA World Factbook (2013). The results show that the differences between countries with Christian and Muslim majorities are less pronounced as compared to the results using the religion data by Parker (1997).

I have also included the KOF indices of globalization (Dreher 2006, and Dreher et al. 2008), which represent an attempt to measure globalization in the broad sense that has been accepted in the recent empirical literature. ${ }^{20}$ It measures globalization on a scale of 1 to 100 , where higher values represent higher levels of globalization and distinguishes between three different dimensions of globalization (economic, social, and political dimension). I have included all three KOF globalization sub indices and the overall KOF index of globalization. The social, political and overall globalization index have a positive influence on the 3P index and including them does not change the inferences regarding the religion and democracy variables.

Migration and trafficking inflows are also likely to influence anti-trafficking policies. I have therefore included net migration (total annual number of immigrants minus the total number of emigrants) and the stock of migrants (share of population) in a country. I use the average data provided by the World Bank for the periods 2001-2010, respectively. The net migration and migration stock variables have the expected positive signs and have a statistically significant influence on the overall $3 \mathrm{P}$ index. Including these variables does not change the inferences regarding the religion and political institution variables at all.

I have also included an index capturing the incidence of human trafficking into a country taken for the Index on Incidence of Reporting of Destination Countries provided by the UNODC Report.

\footnotetext{
${ }^{20}$ The KOF index has frequently been used to measure globalization in recent empirical research on the influence of globalization on human development and economic policy-making (see, for example, Bergh and Nilsson 2010a, $2010 \mathrm{~b})$. Globalization has influenced the empowerment of women. See, for example, Neumayer and de Soysa (2007, 2011), Cho (2012) and Dreher et al. (2012).
} 
The index assumes ordinal scores from 0 (no reported inflow of human trafficking) and 5 (very high inflows) and is used in related studies such as Cho et al. (2013b). Including this index reduces the sample size to 147 countries and does not change the inferences regarding the types of religion variables at all.

The reported effects could also be driven or mitigated by idiosyncratic circumstances in individual countries. For this reason, I checked whether the results are sensitive to the inclusion/exclusion of particular countries. The results (not reported here) indicate that this is not the case.

\section{Conclusion}

I have investigated empirically the role of religion and political institutions on policies against human trafficking as measured by the new 3P Anti-trafficking Policy Index and its sub indices on prosecution, protection and prevention policies. The results show that countries with Christian majorities have relatively strict anti-trafficking policies as compared to countries with Muslim majorities. The differences between countries with Christian and Muslim majorities is pronounced in dictatorships but less so in democracies. The influence of the Muslim share variable on the overall 3P Anti-trafficking Policy Index is driven by protection and prevention policies. As compared to prosecution policies that mainly target the perpetrators of human trafficking, protection and prevention policies mainly protect the victims of human trafficking, who are women. Autocratic rulers in Muslim-dominated countries may well not protect women from being objects of trafficking. The conclusion is consistent with empirical findings describing the association between religion, political institutions and human development that show that Muslim dominated countries discriminate against women. However, democracy ameliorates the gender bias presumably because women vote. Women's suffrage is relevant: empirical research has shown, for example, that the size of government, especially social expenditures increased when women had the right to vote (Lott and Kenny 1999, Aidt and Dallal 2008). In a similar vein, mitigating gender 
disparities in elected office is likely to promote gender equality and stricter anti-trafficking policies.

Future research needs to be done on how policies against human trafficking reduce trafficking as such. 


\section{References}

Aidt, T.S., \& Dallal, B. (2008). Female voting power: the contribution of women's suffrage to the growth of social spending in Western Europe (1869-1960).

Public Choice 134, 391-417.

Akee, R.K.Q., Basu, A.K, Chau, N.H., \& Khamis, M., (2010). Ethnic fragmentation, conflict, displaced persons and human trafficking: an empirical analysis.

IZA Discussion Paper No. 5142.

Alesina, A., Devleeschauwer, A., Easterly, W., Kurlat, S. \& Wacziarg, R., (2003).

Fractionalization. Journal of Economic Growth 8, 155-194.

Barro, R. (1999). Determinants of democracy.

Journal of Political Economy 107, S158-S183.

Becker, S.O, \& Woessmann, L., (2008). Luther and the girls: denomination and the female education gap in ninetieth-century Prussia. Scandinavian Journal of Economics 110, 777-805.

Becker, S.O., \& Woessmann, L., (2010). The effect of Protestantism on education before industrialization: evidence from 1816 Prussia. Economics Letters 107, 224-228.

Belser, P. (2005). Forced labour and human trafficking: Estimating the profits. Working Paper (Declaration/WP/42/2005). International Labour Office. Geneva.

Bennett, C. (2010). Muslim women of power-Gender, politics and culture in Islam. Continuum. London.

Berdiev, A.N, Y. Kim, \& Chang, C.-C. (2012). The political economy of exchange rate regimes in developed and developing countries. European Journal of Political Economy 28, $38-53$.

Berggren, N. (1997). Rhetoric or reality? An economic analysis of the effects of religion in Sweden. Journal of Socio-Economics 26, 571-596.

Berggren, N., \& Bjørnskov, C. (2011). Is the importance of religion in daily life related to social trust? Cross-country and cross-state comparisons.

Journal of Economic Behavior \& Organization 80, 459-480.

Berggren, N., \& Bjørnskov, C. (2013). Does religiosity promote property rights and the rule of law? Journal of Institutional Economics 9, 161-185.

Bergh, A., \& Nilsson, T. (2010a). Good for living? On the relationship between globalization and life expectancy. World Development 38, 1191-1203.

Bergh, A., \& Nilsson, T. (2010b). Do liberalization and globalization increase income inequality? European Journal of Political Economy 26, 488-505. 
Bergh, A., \& Bjørnskov, C. (2011). Historical trust levels predict the current size of the welfare state. Kyklos 64, 1-19.

Bernstein, (2010). Militarized humanitarianism meets carceral feminism: the politics of sex, rights and freedom in contemporary antitrafficking campaigns.

Signs: Journal of Women in Culture and Society 36(1), 45-71.

Bettio, F., \& Nandi, T.K. (2010). Evidence on women trafficked for sexual exploitation: A rights based analysis. European Journal of Law and Economics 29, 15-42.

Borooah, V.K., \& Paldam, M. (2007). Why is the world short of democracy? A cross-country analysis of barriers to representative government. European Journal of Political Economy $23,582-604$.

Branisa, B., Klasen, S. \& Ziegler, M. (2009). New measures of gender inequality: the social institutions and gender index (SIGI) and its subindices. Courant Research Centre: Poverty, Equity and Growth - Discussion Papers 10, Courant Research Centre PEG.

Caraway, T.L. (2009). Comparative political economy, gender, and labor markets. Politics \& Gender 5, 568-575.

Charrad, M.M. (2009). Kinship, Islam, or oil: Culprits of gender inequality? Politics \& Gender 5, 546-553.

Cheibub, J., Gandhi, J., \& Vreeland, J.R. (2010). Democracy and dictatorship revisited. Public Choice 143, 67-101.

Cho, S.-Y. (2012). Modelling for determinants of human trafficking. Economics of Security Working Paper No. 70, Berlin.

Cho, S.-Y. (2013). Integrating inequality - Globalization, women's rights, son preference and human trafficking. International Studies Quarterly, forthcoming.

Cho, S.-Y., Dreher, A. \& Neumayer, E. (2013a). The Spread of Anti-trafficking Policies Evidence from a New Index. Scandinavian Journal of Economics, forthcoming.

Cho, S.-Y., Dreher, A. \& Neumayer, E. (2013b). Does legalization of prostitution increase human trafficking. World Development 41, 67-82.

Cho, S.-Y., \& Vadlamannati, K.C. (2012). Compliance for Big Brothers - An Empirical Analysis on the Impact of the Anti-trafficking Protocol.

European Journal of Political Economy 28, 249-265.

CIA World Factbook (2013). Field Listing: Religions. https://www.cia.gov/library/publications/the-world-factbook/fields/2122.html accessed on February 26, 2013. 
Cingranelli, D.L. \& Richards, D.L. (2010). The Cingranelli-Richards (CIRI) Human Rights Dataset. Available at http://www.humanrightsdata.org.

Cooray, A., \& Potrafke, N. (2011). Gender inequality in education: political institutions or culture and religion? European Journal of Political Economy 27, 268-280.

Coşgel, M., Miceli, T. \& Ahmed, R. (2009). Law, state power, and taxation in Islamic history. Journal of Economic Behavior \& Organization 71, 704-717.

Di Tommaso, M.L., I. Shima, S. Strom \& Bettio, F. (2009). As bad as it gets: Well-being deprivation of sexually exploited trafficked women. European Journal of Political Economy 25, 143-162.

Donno, D., \& Russett, B. (2004). Islam, authoritarianism, and female empowerment. World Politics 56, 582-607.

Dreher, A. (2006). Does globalization affect growth? Evidence from a new index of globalization. Applied Economics 38, 1091-1110.

Dreher, A., Gassebner, M. \& Siemers, L.-H. (2012). Globalization, economic freedom and human rights. Journal of Conflict Resolution 56, 509-539.

Dreher, A., Gaston, N., \& Martens, P., (2008). Measuring globalization - Gauging its consequences. Springer, Berlin.

Facchini, F. (2010). Religion, law and development: Islam and Christianity - Why is it in occident and not in the orient that man invented the institutions of freedom? European Journal of Law and Economics 29(1), 103-129.

Fadel, M. (2012). Muslim reformists, female citizenship, and the public accommodation of Islam in liberal democracy. Politics and Religion 5, 2-35.

Fish, S. (2002). Islam and authoritarism. World Politics 55, 4-37.

Friedrich, R.J. (1982). In defence of multiplicative terms in multiple regression equations. American Journal of Political Science 26, 797-833.

Gauri, V. (2011). The cost of complying with human rights treaties: the Convention on the Rights of the Child and Basic Immunization. Review of International Organizations 6, 33-56.

Gouda, M. (2013). Islamic constitutionalism and rule of law: a constitutional economics perspective. Constitutional Political Economy 24, 57-85.

Gray, M.M., Kittilson, M.C., \& Sandholtz, W. (2006). Women and globalization: A study of 180 countries, 1975-2000. International Organization 60, 293-333.

Groh, M., \& Rothschild, C. (2012). Oil, Islam, women and geography: A comment on Ross (2008). Quarterly Journal of Political Science 7, 69-87. 
Guiso, L., Sapienza, P., \& Zingales, L. (2003). People's opium? Religion and economic attitudes. Journal of Monetary Economics 50, 225-282.

Halverson, J.R., \& Way, A.K. (2011). Islamist feminism: Constructing gender identities in postcolonial Muslim societies. Politics and Religion 4, 503-525.

Hillman, A.L. (2004). Nietzschean development failures. Public Choice 119, 263-280.

Hillman, A.L. (2007a). Economic and security consequences of supreme values.

Public Choice 131(3-4), 259-280. Reprinted as: Hillman, A. L. (2008). An economic perspective on radical Islam. In Frisch, A., Inbar, E. (Eds.), Radical Islam and International Security: Challenges and Responses. Routledge, London, pp. 44-69.

Hillman, A.L. (2007b). Democracy and low-income countries. In Casas Pardo, J., Schwartz, P (Eds.), Public Choice and Challenges of Democracy. Edward Elgar, Cheltenham U.K., pp. 277-294.

Hillman, A.L. (2009). Public finance and public policy. 2nd edition. Cambridge University Press. Cambridge.

Hillman, A.L. (2010). Expressive behavior in economics and politics. European Journal of Political Economy 26, 403-418.

Iannaccone, L.R. (1998). Introduction to the economics of religion. Journal of Economic Literature 36, 1465-1496.

Inglehart, R. \& Norris, P. (2003). Rising tide: gender equality and cultural change around the world. Cambridge University Press. New York and Cambridge.

Kalyvitis, S., \& Vlachaki, I. (2012). When does more aid imply less democracy? An empirical examination. European Journal of Political Economy 28, 132-146.

Kang, A. (2009). Studying oil, Islam, and women as if political institutions mattered. Politics \& Gender 5, 560-568.

Karatnycky, A. (2002). Muslim countries and the democracy gap. Journal of Democracy 13, 99-112.

Kilby, C., \& Scholz, S.J. (2011). The impact of globalization on women - Testing Vandana Shiva's critique of development. Villanova University, mimeo.

Kuran, T. (1997). Islam and underdevelopment: an old puzzle revisited. Journal of Institutional and Theoretical Economics 153, 41-71.

Kuran, T. (2005). The logic of financial westernization in the Middle East. Journal of Economic Behavior \& Organization 56, 593-615.

Kuran, T. (2011). The long divergence - how Islamic law held back the Middle East. Princeton University Press. Princeton and Oxford. 
Kuran, T., \& Lustig, S. (2012). Judicial biases in Ottoman Istanbul - Islamic justice and its compatibility with modern economic life. Journal of Law and Economics 55, 631-666.

Kuran, T., \& Singh, A. (2013). Economic modernization in late British India: Hindu-Muslim differences. Economic Development and Cultural Change 61, 503-538.

La Porta, R., Lopez-di-Silanes, F., Shleifer, A., \& Vishny, R. (1999). The quality of government. Journal of Law, Economics and Organization 15, 222-279.

Lipset, S.M. (1994). The social requisits of democracy revisited.

American Sociology Review 59, 1-22.

Lott R, Kenny L (1999). How dramatically did women's suffrage change the size of government? Journal of Political Economy 107, 1163-1198.

Maffei, A., Raabe, N., \& Ursprung, H.W. (2006). Political repression and child labor: Theory and empirical evidence. World Economy 29, 211-239.

Marshall, M., \& Jaggers, K. (2011). Polity IV Country Reports.

Mattar, M.Y. (2002). Trafficking in persons, especially women and children, in countries of the Middle East: The scope of the problem and the appropriate legislative responses. Fordham International Law Journal 26, 721-760.

Mawdudi, A.A. (1972). Purdah and the status of women in Islam. 2nd edition ( $1^{\text {st }}$ edition 1939). Islamic Publications Ltd. Lahore.

Midlarsky, M. (1998). Democracy and Islam: Implications for civilizational conflict and the democratic peace . International Studies Quarterly 42, 485-511.

Munck, G., \& Verkuilen, J. (2002). Conceptualizing and measuring democracy: Evaluating alternative indices. Comparative Political Studies 55, 5-34.

Nautz, J., \& Sauer, B. (Eds.) (2008). Frauenhandel. Diskurse und Praktiken. V \& R unipress. Göttingen.

Neumayer, E., \& de Soysa, I. (2007). Globalization, Women's economic rights and forced labor. World Economy 1510-1535.

Neumayer, E., \& de Soysa, I. (2011). Globalization and the empowerment of women: an analysis of spatial dependence via trade and foreign direct investment. World Development 39, 1065-1075.

Norris, P. (2009a). Why do Arab states lag the world in gender equality? RWP09-020. Harvard Kennedy School.

Norris, P. (2009b). Petroleum patriarchy? A response to Ross. Politics \& Gender 5, 553-560. 
Norris, P. (2011). Mecca or oil? Why Arab states lag in gender equality

Paper prepared for the Global Cultural Changes Conference, University of California, Irvine, March $11^{\text {th }} 2011$.

Norris, P., \& Inglehart, R. (2003). Muslims and the West: testing the "Clash of Civilizations" thesis. Comparative Sociology 1, 235-265.

Norris, P., \& Inglehart, R. (2004). Scared and secular: politics and religion worldwide. Cambridge University Press. New York and Cambridge.

Norton, S.W., \& Tomal, A. (2009). Religion and female educational attainment. Journal of Money, Credit and Banking 41, 961-986.

Omar Mahmoud, T., \& Trebesch, C. (2010). The economics of human trafficking and labour migration: Micro-evidence from Eastern Europe. Journal of Comparative Economics 38, 173-188.

Parker, P.M. (1997). National cultures of the world: a statistical reference. Greenwood Press. Princeton and Oxford.

Potrafke, N. (2012). Islam and democracy. Public Choice 151, 185-192.

Potrafke, N. (2013). Democracy and countries with Muslim majorities: A reply and update. Public Choice 154, 323-332.

Potrafke, N., \& Ursprung, H.W. (2012). Globalization and gender equality in the course of development. European Journal of Political Economy 28, 39-413.

Rao, S., \& Presenti, C. (2012). Understanding human trafficking origin: A cross-country empirical analysis. Feminist Economics 18, 231-263.

Rode, M.D., \& Gwartney J.D. (2012). Does democratization facilitate economic liberalization? European Journal of Political Economy 28, 607-619.

Ross, M.L. (2001). Does oil hinder democracy? World Politics 53, 325-361.

Ross, M.L. (2008). Oil, Islam and women. American Political Science Review 102, 107-123.

Ross, M.L. (2009a). Does oil wealth hurt women? A reply to Caraway, Charrad, Kang, and Norris. Politics \& Gender 5, 575-582.

Ross, M.L. (2009b). Oil and democracy revisited. Working Paper, UCLA, Los Angeles.

Ross, M.L. (2012a). What is so special about the Arabian peninsula? A reply to Groh and Rothschild. Quarterly Journal of Political Science 7, 89-103.

Ross, M.L. (2012b). The oil curse: how petroleum wealth shapes the development of nations. Princeton University Press, Princeton.

Rowley, C.K., \& Smith, N. (2009). Islam's democracy paradox: Muslims claim to like democracy, so why do they have so little? Public Choice 139, 273-299. 
Rubin, J., (2011). Institutions, the rise of commerce and the persistence of laws: interest restrictions in Islam and Christianity. Economic Journal 121, 1310-1339.

Seguino, S. (2011). Help or hindrance? Religion's impact on gender inequality in attitudes and outcomes. World Development 39, 1308-1321.

Simmons, B., \& Lloyd, P. (2010). Subjective frames and rational choice: Transnational crime and the case of human trafficking. Government Department, Harvard University.

Summers, R., \& Heston, A. (1991). The Penn World Table (Mark 5): an expanded set of international comparisons, 1950-1988. Quarterly Journal of Economics 106, 327-369.

Tripp, A. (2009). Debate: Does oil wealth hurt women? Politics \& Gender 5, 545-546.

United Nations Office on Drugs and Crime (2006). Trafficking in persons global pattern. Vienna.

United Nations Office on Drugs and Crime (2010). Combatting trafficking in persons in accordance with the principles of Islamic law.Vienna.

Voigt, S. (2005). Islam and the institutions of a free society. Independent Review 10, 59-82.

Vreeland, J.R. (2008). The effect of political regime on civil war: Unpacking anocracy. Journal of Conflict Resolution 52, 401-425.

Weber, M. (1905). The Protestant ethic and the spirit of capitalism. (reprint 1956). Unwin. London.

Woodberry, R.D. (2012). The missionary roots of liberal democracy. American Political Science Review 106, 244-274.

Zimmerman, Y.C (2011). Christianity and human trafficking. Religion Compass 5, 567-578. 


\section{Appendix}

Table A1: Description of the Anti-trafficking index

\section{Prosecution:}

The sub-index on 'prosecution policy' measures the level of governments' efforts to punish and prosecute traffickers and other related offenders (such as employers of trafficking victims, law enforcement officials who collude with traffickers, and clients of services provided by human trafficking victims). The prime requirements for governments to implement are broken down into six areas: (i) the adoption of anti-trafficking law, (ii) the adoption of child trafficking law, (iii) the application of other relevant laws, (iv) the stringency of penalties, (v) the level of law enforcement, and (vi) the collection of crime statistics.

\section{Protection:}

The sub-index on 'protection policy' assesses the level of governmental efforts to protect and assist the victims of human trafficking. Nine prime requirements imposed by the Protocol (article 6,7 and 8) are evaluated: (i) no punishment of victims, (ii) imposing no self-identification in order to prove their status as a victim; (iii) assistance for legal proceedings, (iv) the provision of residence permits, (v) basic services for housing, (vi) medical training, (vii) job training, (viii) assistance for rehabilitation and (ix) assistance for repatriation.

\section{Prevention:}

The index on 'prevention policy', evaluates the level of governmental efforts to prevent and combat human trafficking. Based on the requirements of the Protocol provided in article 9, 10, 11, 12 and 13, seven areas are evaluated. Examples are the implementation of campaigns for antitrafficking awareness; training government and military officials (including peace keepers); facilitating information exchange among relevant authorities; monitoring borders, train stations, airports, etc.; adopting national action plans for combating trafficking in persons; promoting cooperation with NGOs and international organizations; and facilitating cooperation with other governments.

Source: Cho et al. (2011: 7ff.)

Table A2: Correlations between the Anti-trafficking indices

\begin{tabular}{l|llll}
\hline & Overall 3P & Prosecution & Protection & Prevention \\
\hline Overall 3P & 1 & & & \\
Prosecution & 0.89 & 1 & & \\
Protection & 0.92 & 0.70 & 1 & 1 \\
Prevention & 0.92 & 0.70 & 0.85 & \\
\hline
\end{tabular}

Source: Cho et al. (2013a) 
Table A3. List of countries included.

\begin{tabular}{|c|c|c|c|c|c|c|c|c|c|}
\hline Country & $3 \mathbf{P}$ & $\begin{array}{c}\text { Christi- } \\
\text { anity }\end{array}$ & Islam & $\begin{array}{l}\text { Demo- } \\
\text { cracy }\end{array}$ & Country & $3 \mathbf{P}$ & $\begin{array}{c}\text { Christi- } \\
\text { anity }\end{array}$ & Islam & $\begin{array}{l}\text { Demo- } \\
\text { cracy }\end{array}$ \\
\hline Afghanistan & 6.7 & 0 & 89 & 0 & Denmark & 13.7 & 89 & 1 & 1 \\
\hline Albania & 11.5 & 33 & 65 & 1 & Djibouti & 6.1 & 5 & 94 & 0 \\
\hline Algeria & 4.6 & 0.4 & 99 & 0 & Dominican Republic & 9.1 & 92 & 0 & 1 \\
\hline Angola & 7.4 & 90 & 0 & 0 & Ecuador & 9.9 & 92 & 0 & 0.80 \\
\hline Antigua and Barbuda & 8.7 & 96 & 0 & 1 & Egypt & 5.9 & 10 & 88 & 0 \\
\hline Argentina & 9.9 & 95 & 0 & 1 & El Salvador & 9.9 & 92 & 0 & 1 \\
\hline Armenia & 10.1 & 97 & 3 & 1 & Equatorial Guinea & 7.7 & 85 & 0.5 & 0 \\
\hline Australia & 14.1 & 74 & 0 & 1 & Eritrea & 4 & 20 & 80 & 0 \\
\hline Austria & 13.7 & 88 & 2 & 1 & Estonia & 8.9 & 100 & 0 & 1 \\
\hline Azerbaijan & 8.9 & 11 & 80 & 0 & Ethiopia & 9.7 & 53 & 32 & 0 \\
\hline Bahamas & 6.2 & 83 & 0 & 1 & Fiji & 7.2 & 52 & 8 & 0.10 \\
\hline Bahrain & 6.8 & 7 & 90 & 0 & Finland & 11.9 & 88 & 0 & 1 \\
\hline Bangladesh & 11.1 & 0 & 87 & 0.78 & France & 12.7 & 82 & 3 & 1 \\
\hline Barbados & 5.8 & 59 & 0 & 1 & Gabon & 10.2 & 96 & 0.8 & 0 \\
\hline Belarus & 9.5 & 68 & 0 & 0 & Gambia & 7.6 & 4 & 94 & 0 \\
\hline Belgium & 14.5 & 79 & 3 & 1 & Georgia & 10.2 & 83 & 11 & 0.50 \\
\hline Belize & 8.9 & 89 & 0 & 1 & Germany & 14.6 & 61 & 2 & 1 \\
\hline Benin & 9.5 & 23 & 13 & 1 & Ghana & 9.8 & 62 & 16 & 1 \\
\hline Bolivia & 8.7 & 93 & 0 & 1 & Greece & 9.8 & 98 & 2 & 1 \\
\hline Bosnia and Herzegovina & 11 & 52 & 43 & 0 & Guatemala & 10.1 & 98 & 0 & 1 \\
\hline Botswana & 6.8 & 48 & 0 & 0 & Guinea & 8.5 & 2 & 80 & 0 \\
\hline Brazil & 11 & 78 & 0 & 1 & Guinea Bissau & 7.7 & 6 & 34 & 0.80 \\
\hline Brunei Darussalam & 5.7 & 10 & 63 & 0 & Guyana & 9 & 41 & 0 & 0 \\
\hline Bulgaria & 11 & 78 & 13 & 1 & Haiti & 6 & 94 & 0 & 0 \\
\hline Burkina Faso & 9.5 & 12 & 42 & 0 & Honduras & 8.9 & 98 & 0 & 1 \\
\hline Burundi & 7.7 & 79 & 1 & 0.40 & Hungary & 10.6 & 82 & 0 & 1 \\
\hline Cambodia & 9.2 & 0 & 2 & 0 & Iceland & 10.3 & 97 & 0 & 1 \\
\hline Cameroon & 7.6 & 52 & 22 & 0 & India & 9.5 & 2 & 11 & 1 \\
\hline Canada & 12.6 & 87 & 0.4 & 1 & Indonesia & 9 & 9 & 81 & 1 \\
\hline Central African Republic & 6.5 & 69 & 8 & 0.40 & Iran & 6.3 & 0.7 & 98 & 0 \\
\hline Chad & 6.9 & 33 & 43 & 0 & Iraq & 4.1 & 4 & 94 & 0 \\
\hline Chile & 11.1 & 87 & 0 & 1 & Ireland & 11.7 & 96 & 0 & 1 \\
\hline China & 10.3 & 0.2 & 2 & 0 & Israel & 10.4 & 2 & 10 & 1 \\
\hline Colombia & 11.9 & 93 & 0 & 1 & Italy & 13.8 & 82 & 0 & 1 \\
\hline Comoros & 6 & 0.6 & 99 & 0.50 & Jamaica & 9.3 & 58 & 0 & 1 \\
\hline Congo & 7 & 78 & 1 & 0 & Japan & 9.5 & 2 & 0 & 1 \\
\hline Costa Rica & 9.5 & 88 & 0 & 1 & Jordan & 7.3 & 5 & 92 & 0 \\
\hline Cote d'Ivoire & 7.8 & 20 & 20 & 0 & Kazakhstan & 9.7 & 17 & 47 & 0 \\
\hline Croatia & 12.2 & 89 & 1 & 1 & Kenya & 9 & 73 & 6 & 1 \\
\hline Cuba & 4.2 & 36 & 0 & 0 & Kiribati & 4.8 & 95 & 0 & 1 \\
\hline Cyprus & 10.3 & 78 & 19 & 1 & Kuwait & 6.3 & 0 & 85 & 0 \\
\hline Czech Republic & 12.5 & 48 & 0 & 1 & Kyrgyzstan & 8.9 & 20 & 70 & 0.40 \\
\hline $\begin{array}{l}\text { Democratic People's Republic of } \\
\text { Korea }\end{array}$ & 3 & 0.9 & 0 & 0 & $\begin{array}{l}\text { Lao People's Democratic } \\
\text { Republic }\end{array}$ & 9.2 & 2 & 1 & 0 \\
\hline $\begin{array}{l}\text { Democratic Republic of the } \\
\text { Congo }\end{array}$ & 7.3 & 94 & 1 & 0 & Latvia & 10.7 & 65 & 0 & 1 \\
\hline
\end{tabular}


Table A3. List of countries included (continued).

\begin{tabular}{|c|c|c|c|c|c|c|c|c|c|}
\hline Country & $3 \mathbf{P}$ & $\begin{array}{c}\text { Christi- } \\
\text { anity }\end{array}$ & Islam & $\begin{array}{l}\text { Demo- } \\
\text { cracy }\end{array}$ & Country & $3 \mathbf{P}$ & $\begin{array}{c}\text { Christi- } \\
\text { anity }\end{array}$ & Islam & $\begin{array}{l}\text { Demo- } \\
\text { cracy }\end{array}$ \\
\hline Lebanon & 6 & 15 & 50 & 0 & Saint Lucia & 8 & 95 & 0 & 1 \\
\hline Lesotho & 7 & 93 & 0 & 0 & $\begin{array}{l}\text { Saint Vincent and the } \\
\text { Grenadines }\end{array}$ & 6.3 & 90 & 0 & 1 \\
\hline Liberia & 7.4 & 67 & 14 & 0.30 & Saudi Arabia & 6.3 & 0.8 & 99 & 0 \\
\hline Libya & 4.6 & 0 & 97 & 0 & Senegal & 9.6 & 5 & 91 & 0.90 \\
\hline Lithuania & 12.4 & 95 & 0 & 1 & Serbia & 9.1 & 70 & 19 & 0.87 \\
\hline Luxembourg & 12.4 & 93 & 0 & 1 & Seychelles & 6 & 97 & 0 & 0 \\
\hline Macedonia & 11.5 & 64 & 26 & 1 & Sierra Leone & 7.6 & 8 & 39 & 1 \\
\hline Madagascar & 8.8 & 50 & 3 & 1 & Singapore & 8.8 & 16 & 16 & 0 \\
\hline Malawi & 10.7 & 64 & 16 & 1 & Slovakia & 10.6 & 80 & 0 & 1 \\
\hline Malaysia & 7.9 & 6 & 53 & 0 & Slovenia & 11.9 & 96 & 1 & 1 \\
\hline Maldives & 4.7 & 0 & 100 & 0.1 & Solomon Islands & 4 & 93 & 0 & 1 \\
\hline Mali & 8.3 & 1 & 89 & 1 & Somalia & 3.2 & 0.1 & 100 & 0 \\
\hline Malta & 9.4 & 97 & 0 & 1 & South Africa & 7.4 & 68 & 1 & 0 \\
\hline Mauritania & 7.3 & 0.4 & 99 & 0.10 & Spain & 13.5 & 96 & 0 & 1 \\
\hline Mauritius & 10.9 & 30 & 13 & 1 & Sri Lanka & 9.5 & 8 & 8 & 1 \\
\hline Mexico & 9 & 96 & 0 & 0.90 & Sudan & 4.5 & 8 & 73 & 0 \\
\hline Mongolia & 9 & 0 & 1 & 1 & Suriname & 8.4 & 41 & 20 & 1 \\
\hline Montenegro & 9.5 & 70 & 19 & 0 & Swaziland & 6.4 & 77 & 0 & 0 \\
\hline Morocco & 9 & 1 & 99 & 0 & Sweden & 13.7 & 80 & 0 & 1 \\
\hline Mozambique & 8.4 & 31 & 13 & 0 & Switzerland & 12.4 & 92 & 2 & 1 \\
\hline Myanmar & 7 & 5 & 4 & 0 & Syria & 5.6 & 8 & 90 & 0 \\
\hline Namibia & 7.5 & 82 & 0 & 0 & Taiwan & 10.2 & 7 & 0.5 & 1 \\
\hline Nepal & 10.3 & 0.2 & 3 & 0.40 & Tajikistan & 9.3 & 0 & 85 & 0 \\
\hline Netherlands & 14.2 & 62 & 3 & 1 & Thailand & 11.8 & 1 & 4 & 0.80 \\
\hline New Zealand & 12.1 & 63 & 0 & 1 & Togo & 8.1 & 35 & 12 & 0 \\
\hline Nicaragua & 9.1 & 92 & 0 & 1 & Tonga & 6 & 93 & 0 & 0 \\
\hline Niger & 8.6 & 0 & 90 & 0.90 & Trinidad and Tobago & 7 & 55 & 6 & 1 \\
\hline Nigeria & 11 & 49 & 45 & 1 & Tunisia & 5.9 & 0.3 & 99 & 0 \\
\hline Norway & 14.3 & 92 & 0 & 1 & Turkey & 10.2 & 0.3 & 99 & 1 \\
\hline Oman & 7.9 & 0 & 87 & 0 & Turkmenistan & 4.2 & 11 & 87 & 0 \\
\hline Pakistan & 9.3 & 2 & 97 & 0.10 & Uganda & 8.3 & 76 & 7 & 0 \\
\hline Panama & 10.1 & 89 & 5 & 1 & Ukraine & 10.3 & 90 & 8 & 1 \\
\hline Papua New Guinea & 6.2 & 91 & 0 & 1 & United Arab Emirates & 8.7 & 4 & 95 & 0 \\
\hline Paraguay & 9.8 & 98 & 0 & 1 & United Kingdom & 13.1 & 87 & 1 & 1 \\
\hline Peru & 9.5 & 98 & 0 & 0.80 & United Republic of Tanzania & 8.8 & 34 & 33 & 0 \\
\hline Philippines & 11.5 & 88 & 4 & 1 & United States & 15 & 62 & 2 & 1 \\
\hline Poland & 12.5 & 90 & 0 & 1 & Uruguay & 9.9 & 62 & 0 & 1 \\
\hline Portugal & 12.6 & 94 & 0.1 & 1 & Uzbekistan & 9.6 & 9 & 88 & 0 \\
\hline Qatar & 6.1 & 6 & 92 & 0 & Venezuela & 7.3 & 91 & 0 & 1 \\
\hline Republic of Korea & 13.3 & 33 & 0 & 1 & Viet Nam & 11.1 & 7 & 0 & 0 \\
\hline Republic of Moldova & 9.6 & 97 & 0 & 1 & Yemen & 7.1 & 0 & 100 & 0 \\
\hline Romania & 11.4 & 90 & 0.2 & 1 & Zambia & 10 & 69 & 0.3 & 0 \\
\hline Russian Federation & 9.1 & 84 & 5 & 0 & Zimbabwe & 7.3 & 43 & 0 & 0 \\
\hline Rwanda & 9.6 & 74 & 9 & 0 & Total & 9 & 51.59 & 25.57 & 0.55 \\
\hline
\end{tabular}


Table A4. Data description and sources.

\begin{tabular}{|c|c|c|c|c|c|c|}
\hline Variable & Observations & Mean & Std. Dev. & Min & Max & Source \\
\hline $\begin{array}{l}\text { 3P index } \\
\text { (prosecution) }\end{array}$ & 175 & 3.35 & 1.07 & 1 & 5 & $\begin{array}{l}\text { Cho et al. } \\
\text { (2011) }\end{array}$ \\
\hline $\begin{array}{l}\text { 3P index } \\
\text { (protection) }\end{array}$ & 175 & 2.64 & 0.89 & 1 & 5 & $\begin{array}{l}\text { Cho et al. } \\
\text { (2011) }\end{array}$ \\
\hline $\begin{array}{l}\text { 3P index } \\
\text { (prevention) }\end{array}$ & 175 & 3.05 & 0.83 & 1 & 5 & $\begin{array}{l}\text { Cho et al. } \\
\text { (2011) }\end{array}$ \\
\hline 3P index (overall) & 175 & 9.04 & 2.54 & 3 & 15 & $\begin{array}{l}\text { Cho et al. } \\
\text { (2011) }\end{array}$ \\
\hline Democracy & 175 & 0.55 & 0.48 & 0 & 1 & $\begin{array}{l}\text { Cheibub et al. } \\
(2010)\end{array}$ \\
\hline Anglicans share & 175 & 2.31 & 8.11 & 0 & 57 & Parker (1997) \\
\hline Buddhists share & 175 & 3.59 & 14.93 & 0 & 92 & Parker (1997) \\
\hline Christians share & 175 & 51.59 & 38.03 & 0 & 100 & Parker (1997) \\
\hline Hindus share & 175 & 2.36 & 10.84 & 0 & 86 & Parker (1997) \\
\hline Jews share & 175 & 0.58 & 6.35 & 0 & 84 & Parker (1997) \\
\hline Muslims share & 175 & 25.57 & 36.82 & 0 & 100 & Parker (1997) \\
\hline Protestants share & 175 & 13.86 & 23.06 & 0 & 100 & Parker (1997) \\
\hline $\begin{array}{l}\text { Roman Catholics } \\
\text { share }\end{array}$ & 175 & 27.54 & 34.25 & 0 & 97 & Parker (1997) \\
\hline $\begin{array}{l}\text { Traditional } \\
\text { religions share }\end{array}$ & 175 & 5.6 & 12.67 & 0 & 63 & Parker (1997) \\
\hline Christian majority & 175 & 0.59 & 0.49 & 0 & 1 & $\begin{array}{l}\text { CIA World } \\
\text { Factbook } \\
\text { (2013) } \\
\text { CIA World }\end{array}$ \\
\hline Muslim majority & 175 & 0.29 & 0.45 & 0 & 1 & $\begin{array}{l}\text { Factbook } \\
\text { (2013) } \\
\text { CIA World }\end{array}$ \\
\hline Hindu majority & 175 & 0.02 & 0.15 & 0 & 1 & $\begin{array}{l}\text { Factbook } \\
(2013) \\
\text { CIA World }\end{array}$ \\
\hline Buddhist majority & 175 & 0.05 & 0.21 & 0 & 1 & $\begin{array}{l}\text { Factbook } \\
(2013) \\
\text { CIA World }\end{array}$ \\
\hline Jewish majority & 175 & 0.01 & 0.08 & 0 & 1 & $\begin{array}{l}\text { Factbook } \\
(2013)\end{array}$ \\
\hline $\begin{array}{l}\text { Indigenous } \\
\text { majority }\end{array}$ & 175 & 0.05 & 0.21 & 0 & 1 & $\begin{array}{l}\text { CIA World } \\
\text { Factbook } \\
\text { (2013) }\end{array}$ \\
\hline Religiosity & 152 & 0.72 & 0.25 & 0.15 & 1 & $\begin{array}{l}\text { Berggren \& } \\
\text { Bjørnskov } \\
(2013)\end{array}$ \\
\hline British legal origin & 173 & 0.31 & 0.46 & 0 & 1 & $\begin{array}{l}\text { La Porta et al. } \\
\text { (1999) }\end{array}$ \\
\hline French legal origin & 173 & 0.43 & 0.5 & 0 & 1 & $\begin{array}{l}\text { La Porta et al. } \\
\text { (1999) }\end{array}$ \\
\hline $\begin{array}{l}\text { Socialist legal } \\
\text { origin }\end{array}$ & 173 & 0.2 & 0.4 & 0 & 1 & $\begin{array}{l}\text { La Porta et al. } \\
\text { (1999) }\end{array}$ \\
\hline $\begin{array}{l}\text { German legal } \\
\text { origin }\end{array}$ & 173 & 0.03 & 0.18 & 0 & 1 & $\begin{array}{l}\text { La Porta et al. } \\
\text { (1999) }\end{array}$ \\
\hline $\begin{array}{l}\text { Scandinavian legal } \\
\text { origin }\end{array}$ & 173 & 0.03 & 0.17 & 0 & 1 & $\begin{array}{l}\text { La Porta et al. } \\
\text { (1999) }\end{array}$ \\
\hline
\end{tabular}


Table A4. Data description and sources (continued).

\begin{tabular}{|c|c|c|c|c|c|c|}
\hline Variable & Observations & Mean & Std. Dev. & Min & Max & Source \\
\hline Africa & 175 & 0.29 & 0.46 & 0 & 1 & own calculation \\
\hline Americas & 175 & 0.18 & 0.39 & 0 & 1 & own calculation \\
\hline Asia & 175 & 0.26 & 0.44 & 0 & 1 & own calculation \\
\hline Europe & 175 & 0.23 & 0.42 & 0 & 1 & own calculation \\
\hline Oceania & 175 & 0.04 & 0.2 & 0 & 1 & own calculation \\
\hline OECD & 175 & 0.17 & 0.38 & 0 & 1 & $\begin{array}{l}\text { own calculation } \\
\text { PENN World }\end{array}$ \\
\hline Population & 173 & 36628.69 & $1.32 \mathrm{E}+05$ & 80.6 & $1.29 \mathrm{E}+06$ & $\begin{array}{l}\text { Table } 7.1 \text {-, } \\
\text { Summers \& } \\
\text { Heston (1991) } \\
\text { PENN World }\end{array}$ \\
\hline $\begin{array}{l}\text { Real GDP per } \\
\text { capita }\end{array}$ & 173 & 11869.43 & 14407.38 & 208.21 & 82448.82 & $\begin{array}{l}\text { Table } 7.1 \text { - } \\
\text { Summers \& } \\
\text { Heston (1991) }\end{array}$ \\
\hline $\begin{array}{l}\text { Oil production } \\
\text { value per capita }\end{array}$ & 174 & 665.2 & 2360.2 & 0 & 18242.41 & $\begin{array}{l}\text { EIA (2012), } \\
\text { own calculation }\end{array}$ \\
\hline Democracy (type2) & 175 & 0.78 & 0.39 & 0 & 1 & $\begin{array}{l}\text { Cheibub et al. } \\
\text { (2010) }\end{array}$ \\
\hline POLITY IV index & 160 & 3.35 & 6.31 & -10 & 10 & $\begin{array}{l}\text { Marshall \& } \\
\text { Jaggers (2011) }\end{array}$ \\
\hline $\begin{array}{l}\text { POLITY IV } \\
\text { executive } \\
\text { constraints }\end{array}$ & 161 & 1.13 & 13.36 & -77 & 7 & $\begin{array}{l}\text { Marshall \& } \\
\text { Jaggers (2011) }\end{array}$ \\
\hline $\begin{array}{l}\text { KOF index of } \\
\text { globalization } \\
\text { (overall) }\end{array}$ & 171 & 55.45 & 17.01 & 21.7 & 92.38 & $\begin{array}{l}\text { Dreher (2006); } \\
\text { Dreher et al. } \\
\text { (2008) }\end{array}$ \\
\hline $\begin{array}{l}\text { KOF index of } \\
\text { globalization } \\
\text { (economic) }\end{array}$ & 146 & 60.07 & 16.95 & 25.74 & 96.38 & $\begin{array}{l}\text { Dreher (2006); } \\
\text { Dreher et al. } \\
\text { (2008) }\end{array}$ \\
\hline $\begin{array}{l}\text { KOF index of } \\
\text { globalization } \\
\text { (social) }\end{array}$ & 171 & 47.35 & 21.81 & 11.85 & 92.13 & $\begin{array}{l}\text { Dreher (2006); } \\
\text { Dreher et al. } \\
\text { (2008) }\end{array}$ \\
\hline $\begin{array}{l}\text { KOF index of } \\
\text { globalization } \\
\text { (political) }\end{array}$ & 174 & 64.08 & 20.36 & 20.56 & 97.26 & $\begin{array}{l}\text { Dreher (2006); } \\
\text { Dreher et al. } \\
\text { (2008) }\end{array}$ \\
\hline $\begin{array}{l}\text { Absence of } \\
\text { corruption }\end{array}$ & 172 & 3.97 & 2.09 & 1.33 & 9.54 & $\begin{array}{l}\text { Transparency } \\
\text { International } \\
\text { (2012) }\end{array}$ \\
\hline $\begin{array}{l}\text { Women's } \\
\text { economic rights }\end{array}$ & 175 & 1.3 & 0.6 & 0 & 3 & $\begin{array}{l}\text { Cingranelli \& } \\
\text { Richards (2010) }\end{array}$ \\
\hline $\begin{array}{l}\text { Trafficking } \\
\text { (transit) }\end{array}$ & 150 & 1.44 & 1.51 & 0 & 5 & UNODC (2006) \\
\hline $\begin{array}{l}\text { Net migration } \\
\text { flows }\end{array}$ & 171 & -797.58 & $6.86 \mathrm{E}+05$ & $-1.92 \mathrm{E}+06$ & $6.56 \mathrm{E}+06$ & $\begin{array}{l}\text { Worldbank } \\
\text { (2011) }\end{array}$ \\
\hline Migrant stock & 174 & 7.66 & 12.04 & 0.05 & 80.24 & $\begin{array}{l}\text { Worldbank } \\
\text { (2011) }\end{array}$ \\
\hline
\end{tabular}

